\title{
Selection of winter durum genotypes grown under conventional and organic conditions in different European regions
}

Péter Mikóal $^{\mathrm{a}}$, Gyula Vida ${ }^{\mathrm{a} 1}$, Marianna Rakszegi ${ }^{\mathrm{a}^{*}}$, Julia Lafferty $^{\mathrm{b}}$, Bruno Lorentz ${ }^{\mathrm{c}}$, Carl Friedrich Horst Longin ${ }^{\mathrm{d}}$, Mária Megyeri ${ }^{\mathrm{a}}$

a Agricultural Institute, Centre for Agricultural Research, Hungarian Academy of Sciences, Brunszvik u. 2, 2462 Martonvásár, Hungary

${ }^{\mathrm{b}}$ Saatzucht Donau GmbH \& Co KG, Saatzuchtstrasse 11, 2301 Probstdorf, Austria

${ }^{\mathrm{c}}$ INRA - UMR Diversity and Genome of Cultivated Plants - Domaine de Melgueil- 34130 Mauguio, France

${ }^{\mathrm{d}}$ State Breeding Institute, University of Hohenheim, Schloss Hohenheim 1, 70599 Stuttgart, Germany

${ }^{1}$ These authors contributed equally to the paper.

ORCID: Péter Mikó: 0000-0003-4915-7415; Marianna Rakszegi: 0000-0003-0798-8974 (not available for the other authors)

*corresponding author: rakszegi.mariann@agrar.mta.hu, Tel: +3622569500 (ext. 142)

\begin{abstract}
Quality and agronomic performance of 14 winter durum wheat genotypes were examined in Austria, France and Hungary for three years. Heading time, wet gluten content, semolina yield and grain protein content are traits that showed genotype-dependent significant differences between the two management systems examined (conventional and organic). Therefore, breeding for these traits could result in specifically adapted genotypes for organic agriculture in different countries. Based on strong or moderately significant correlations between traits, gluten index and plant height could also be specifically selected in an indirect way. The need for environmentally specific selection for grain yield in later generations was also demonstrated. In general, varieties that had the highest performance in a given mega-environment originated from that mega-environment (except for yellow index). This finding provides evidence for the influence of the selection environment, whether it is the management system or the growing region. As the French site fell into a distinct mega-environment, it should be handled separately. The Hungarian site was found to be an ideal test environment for selecting genotypes with high adaptability for most of the quality traits, while the Austrian site could be used in selecting agronomic traits. This was also reflected in the breeding origin of the best winter durum genotypes for each trait. Based on these findings, a partly separate winter durum selection program is recommended for organic and low input agriculture in each country. As a consequence, specific varieties adapted to sub-optimal growing conditions would support the emerging movement towards sustainable farming systems.
\end{abstract}

Key words: durum wheat; GGE biplot; grain quality; low input agriculture; organic breeding; variety performance

\section{Acknowledgements}

This research received funding from the European Community's Seventh Framework Programme (FP7/20072013) under Grant Agreement No. 245058-SOLIBAM (supplementary Hungarian project EU_BONUS_12-12012-0032). Special thanks go to Jürg Hiltbrunner for valuable scientific advice. 


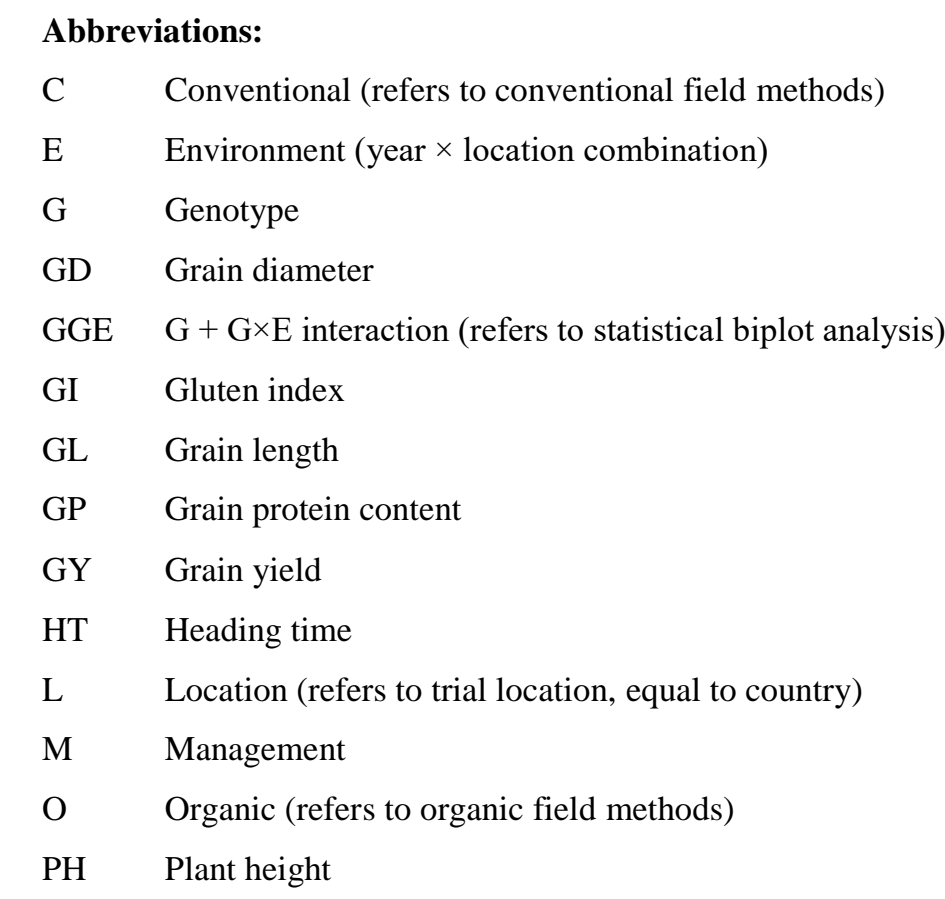

REML REstricted Maximum Likelihood algorithm: estimates variance parameters in linear mixed models

SY Semolina yield

TGW Thousand grain weight

WG Wet gluten content

YI Yellow index

\section{Introduction}

Sustainability is a key factor for the future of agriculture. Productivity in agriculture has more than tripled in developed countries since the 1950s. Beyond the success of plant breeding, the increased use of inorganic fertilizers, application of pesticides, and spread of irrigation also contributed to this success. However, impressive yield increases started to decline in the 1980s because of the lack of sustainability. One of the most beneficial ways to increase sustainability is organic agriculture. In such agro-ecosystem-based holistic production systems the prerequisite of successful farming is the availability of crop genotypes that perform well (Nuijten et al. 2017). Organic agriculture currently lacks crop varieties that can respond to its specific demands, such as high nitrogen use efficiency, competitiveness against weeds and resistance to biotic and abiotic stresses. Although several organic breeding programs have been established, it is estimated that more than $95 \%$ of organic production is still based on crop varieties that were bred for the conventional high-input sector (Lammerts van Bueren et al. 2010). The response of crop genotypes to various management systems differs. In the case of bread wheat, significant management $\times$ genotype $(M \times G)$ interactions were observed for several agronomic characteristics (Murphy et al. 2007; Mikó et al. 2014). Similar observations were reported in spring durum wheat by Giambalvo et al. (2010), whereby modern varieties performed better under high nitrogen levels than the older more extensive ones. However, differences between the new and old varieties were very minor or absent when they were grown in the presence of weed competition and under low $\mathrm{N}$ availability, conditions typical in organic 
farming. Fagnano et al. (2012) observed no significant interaction between cropping systems (conventional and organic) and spring durum genotypes regarding yield and yield components, but average yields in the organic system were $21 \%$ lower than in the conventional one. Modern durum varieties seem unable to express their yield potential when grown under organic or low input farming conditions (Dinelli et al. 2013), so there is a need to develop, or at least identify durum genotypes that can provide adequate performance without high nitrogen inputs by selecting specific traits, such as kernel weight, spike length and kernels/spike (Dinelli et al. 2014). Recently Rakszegi et al. (2016) conducted detailed analyses of quality parameters in organic and conventional field management for winter wheat, but such information is not commonly available for winter durum (e.g. Stagnari et al. 2013). The present study widens knowledge on this topic with the examination of a larger number of quality parameters of winter durum by comparing data from organic and conventional growing conditions in different European countries.

Currently most winter durum is cultivated under conventional conditions. In recent decades the demand for organically produced durum has increased in Europe and the introduction of durum into the crop rotation will increase biodiversity, while the farming practice and machinery requirements remain the same as for bread wheat.

In developed countries, especially in the European Union, priority is given to supporting the spread of, and research on, sustainable agriculture. Breeding programs for organic agriculture have already been launched for several crops, but support for the breeding of organic winter durum cultivars is not common. The aims of this study were to: 1) examine the performance and stability of diverse winter durum genotypes under conventional and organic growing conditions in different European countries in order to 2) identify potential selection environments for European organic winter durum breeding programs, and 3) identify potential traits useful in selecting winter durum genotypes for European organic or low input agriculture.

\section{Materials and methods}

Plant material and field experiment

Fourteen winter durum (Triticum turgidum L. subsp. durum (Desf.) Husn.) varieties and breeding lines were examined in the present study. The varieties originated from six breeding programs in Austria, France, Germany and Hungary (Table 1). These varieties were examined in Austria, France and Hungary between 2011 and 2013 in a randomised small-plot complete block design with 3 replications grown under conventional (C) and organic (O) management conditions. The plots were machine-drilled at the optimal autumn sowing date and combineharvested at full maturity. Net plot size ranged between 6 and $9 \mathrm{~m}^{2}$. Herbicides and artificial fertilizers, but no fungicides, were used in the conventional fields. Weather conditions differed greatly not only between the three countries but also between the three years, especially regarding the amount of precipitation in the last 100 days. Big differences were also measured regarding the soil parameters between the trial locations. Due to the different climatic and soil conditions, different sowing densities (to achieve $350-450$ seedlings $/ \mathrm{m}^{2}$ ) were applied. As the French trial failed in the first trial year, eight environments (year $\times$ trial location combinations) were examined in the two management systems, i.e. a total of 16 experiments (location $\times$ year $\times$ management combinations) were evaluated. Details on geographical, meteorological, soil and growing conditions at the different trial locations are provided in Online Resource 1. 
Assessment of agronomic and technological quality traits

Field assessment, examination of harvested grains and quality tests were carried out according to the list presented in Table 2. All eight quality traits were tested in the wheat quality laboratory at the Centre for Agricultural Research (Hungary). The physical parameters of the seeds, grain length (GL), grain diameter (GD) and thousand grain weight (TGW), were measured with a Marvin Digital Seed Analyser, while gluten properties, wet gluten content (WG) and gluten index (GI), were analysed according to ICC Standard No. 158. Grain protein content (GP) was determined on a dry matter basis by the Kjeldahl method, while semolina yield (SY) and yellow index (YI) were determined with a specific laboratory mill and Minolta CR-300, respectively. The total number of observations was similar in the conventional and organic trials for each trait, the highest number being assessed in the case of grain yield (GY), heading time (HT) and plant height (PH). Although no fungicides were used, disease levels were minimal and considered inconsequential to the experimental outcomes.

\section{Statistical analysis}

The GGE Biplot Analysis module of Genstat 18.0 software (VSN International Ltd., Hemel Hemstead, UK) was used to identify superior winter durum genotypes and ideal breeding sites (country $\times$ management) for selecting generally or specifically adapted genotypes according to the following model:

i)

$$
Y_{i j}-\mu-\beta_{j}=a_{i}+j_{i j}
$$

where $Y_{i j}$ is the measured mean of the $i^{\text {th }}$ genotype in the $j^{\text {th }}$ trial site (country $\times$ management), $\mu$ is the grand mean, $a_{i}$ is the main effect of the $i^{\text {th }}$ genotype, $\beta_{j}$ is the main effect of the $j^{\text {th }}$ trial site and $j_{i j}$ is the interaction between $i^{\text {th }}$ genotype and $j^{\text {th }}$ trial site. The representativeness and discrimination ability of trial sites were determined according to Yan and Tinker (2006): the most representative site was that having the smallest acute angle with the Average-Environment Axis, while the trial site with the longest environmental vector was taken as the most discriminative one. Based on performance and stability the three best genotypes were identified according to the shortest distance from an "ideal" genotype located on the Average-Environment Axis (Yan and Tinker 2006). The best performing genotypes were also determined for each mega-environment (environments that need different varieties based on the performance of genotypes) developed by GGE biplot analysis.

As a proof of the reliability of the trial setup, GGE biplot analysis was also used to show different correlations between the eight environments (year $\times$ location) for each trait. This pre-evaluation of the dataset resulted in the identification of mostly positive correlations, but for each trait (except HT and PH) at least one environment showed a negative correlation with at least two other environments. Moreover, non-correlated environments were also identified for seven traits (GY, GP, WG, SY, YI, TGW and GD), indicating high environmental variability in the present study (Table 2, biplots not shown).

Detailed statistical evaluations were carried out using SPSS 16.0 software (SPSS Inc., Chicago, IL, USA). First, a statistical model was used to evaluate the effect of the different European trial locations (i.e. countries) on the performance of genotypes applying the Linear Mixed Model (using the restricted maximum likelihood 
algorithm, REML) analysis module based on the study of Virk et al. (2009) with some modifications published by Vida et al. (2014):

ii)

Fixed model $=$ Constant $+L+G+L \times G$

Random model $=Y+\varepsilon$

where $L$ represents the trial location (country), $G$ represents the genotype, $L \times G$ is the interaction between them, $Y$ represents the three years of experimentation, and $\varepsilon$ is the residual error term. Using the same model, data originating from the different locations were also analysed with separate management systems.

In order to analyse the different (genotype-dependent) effects of the two management systems, the $M \times G$ interaction was evaluated for the traits with the following full model according to Mikó et al. (2014):

iii) Fixed model $=$ Constant $+E+M+G+E \times M+E \times G+M \times G+E \times M \times G$

Random model $=$ Replication $+\varepsilon$

where $E$ represents the total of eight environments (year $\times$ location combinations) and $M$ represents the management system. In addition, the following linear mixed model was used to evaluate the $M \times G$ interaction for each trial location (country) separately:

$i v)$

Fixed model $=$ Constant $+M+G+M \times G$

Random model $=Y+\varepsilon$

Variance components and broad-sense heritability $\left(h^{2}\right)$ were determined for both the whole trial $(v)$ and the two management systems (vi) using the restricted maximum likelihood (REML) method assuming random models:

v) Random model $=$ Constant $+E+M+G+E \times M+E \times G+M \times G+E \times M \times G+\varepsilon$

vi) $\quad$ Random model $=$ Constant $+E+G+E \times G+\varepsilon$

Repeatability (broad-sense heritability) was calculated on an entry-mean basis as the ratio of genotypic to phenotypic variance according to Melchinger et al. (1998).

Correlations between all the 11 traits assessed were analysed using the Bivariate correlations module in SPSS 16.0 software. The correlation of traits in the two management systems was determined on the basis of Pearson's correlation coefficient using best linear unbiased estimators (BLUE) of the traits according to Longin et al. (2013). Correlation coefficients were calculated separately for the conventional and organic management systems and between the management systems, similarly to those published by Mikó et al. (2014). The strength of correlations was determined according to Evans (1996), who suggested five groups for strength based on the absolute value of the correlation coefficient $(r)$ : very weak (0.00-0.19), weak (0.20-0.39), moderate (0.40-0.59), 
strong (0.60-0.79) and very strong (0.80-1.00). In the present study phenotypic correlation coefficients $\left(r_{P}\right)$ below 0.4 are considered as weak correlations.

\section{Results}

Ideal genotype and selection site based on GGE biplots

The GGE biplots show that the cumulative value of the first two principal components ranged between $84.27 \%$ (SY) and $91.63 \%$ (GI). The pattern of the three best winter durum genotypes, based on the distance from an "ideal" genotype that has high performance with high stability and is located on the Average-Environment Axis, is very complex: 13 of the 14 genotypes are presented and only HOH6012 is not included. Therefore, it is difficult to choose a single superior variety. Based on the occurrence on the first three places, Troubadur (5 times), Lunadur (4 times), Mv Hundur, MvTD07-09, Kiradur, Cliodur and Wintergold (each 3 times) are the most frequent genotypes and Austrian genotypes were generally present the most times (18 of 33). Austrian varieties were the best for grain yield, plant height (close to the trial average), gluten index, yellow index and grain size (TGW, GD and GL), whereas Hungarian varieties were superior for grain protein content, wet gluten content and semolina yield. French varieties were the earliest heading (Table 3 and Online Resource 2).

The which-won-where view of the GGE biplots (Online Resource 2) is a good tool to detect the best performing (but not consistently stable) genotype for each mega-environment. As only genotypes with the highest value of a given trait could be demonstrated as the best ones, plant height and heading time could only be discussed in terms of trial sites, not genotypes. The rank of the best varieties was different within each mega-environment. The German variety HOH6012 was the best in the Austrian trial location for four important traits (GP, SY, WG and YI), but was not included in the first three ideal varieties due to its relatively low stability. In general, varieties that had the highest performance in a given mega-environment originated from that mega-environment, except regarding YI, where Mv Hundur and Kiradur were the best in France and Hungary, respectively (Table 3 and Online Resource 2).

The rank of trial sites was also examined based on different selection aims (Table 3 and Online Resource 2). The trial sites that could be effectively used to select specifically adapted genotypes (culling unstable genotypes) were mostly the French sites FC (10 times, best for HT, GP and SY) and FO (8 times) and the Hungarian sites HC (9 times, best for GY, GI, TGW, GD, GL and YI) and HO (3 times, best for WG). These sites are the most discriminative (highest standard deviation) and non-representative ones among those examined in this study. The Austrian sites could be used efficiently for the selection of agronomic traits (PH, HT and GY). The Hungarian and French trial sites could again be recommended for the selection of generally adapted winter durum genotypes, with some additional Austrian sites in the case of grain size (GD in AC and GL in AO) and yellow index (AO). Nevertheless, based on the mega-environment grouping, the Hungarian conventional and organic sites appeared to be the most appropriate choice for selecting winter durum genotypes, as they were ranked first most frequently (specific adaptation: HC-6, HO-1; general adaptation: HC-4, HO-3), while the French (specific adaptation: FC-3, FO-0; general adaptation: FC-1, FO-1) and Austrian (specific adaptation: AC-1, AO-0; general adaptation: AC-1, AO-1) sites were less frequently found to be ideal selecting environments.

When the six trial sites (country $\times$ management) were analysed using the test environment ranking view of the GGE biplots, a strong country effect was found for YI, as the trial sites in each country formed distinct mega- 
environments (Online Resource 2). At the same time, the effect of the two Climatic Zones (Mediterranean and Continental-Pannonian; classified by Metzger et al. 2005) could be identified for GY and GI. For most of the traits (e.g. TGW, GD, GL, SY, WG and GP), the Hungarian sites exhibited very different site effects being more similar to the Austrian sites under conventional growing conditions (HC) more like in Austria (AC and AO) and more like the French sites (FC and FO) under organic growing conditions (HO). The pattern was different for HT and PH, as all the trial sites could be placed in a single large mega-environment, but the program also indicated one more distinct mega-environment (AO) for HT and two more (HC and FC) for PH (Online Resource 2 and Table 3).

Interaction between genotype and trial location/management

After identifying the ideal winter durum genotypes and selection environments, the main effects of the genotype and the trial location (country) or management system on the traits and their interactions were determined to search for genotype-dependent environmental effects (i.e. significant $L \times G$ or $M \times G$ interactions) (Table 4).

The trial location had a significant $(\mathrm{P} \leq 0.05)$ effect on all the traits except grain yield, which was only found to be significant when the two management systems were analysed separately. All 11 traits were significantly determined by the genotype itself. The trial location $\times$ genotype interaction was significant for 6 traits (HT, GI, TGW, GD, GL and YI) and slightly significant $(\mathrm{P} \leq 0.1)$ for grain protein content, which showed a significant $L \times G$ interaction in the conventional field. The main discriminating traits were very similar for the two management systems separately, but grain yield also showed a significant location $\times$ genotype interaction in the organic field. The $L \times G$ interaction for heading time was only significant for the whole trial, and not for the different management systems (Table 4).

The main effect of the management system was significant for all the traits except HT, SY and GI, while a strong significant genotypic effect was found for all 11 traits. However, main effect of the management system in the different countries was significant except for HT in Hungary and except for GI in France and Hungary. A significant $M \times G$ interaction was detected for HT and WG, while the interaction was only slightly significant for SY. For the separate countries, a significant $M \times G$ interaction was detected in France for GP and WG and a slightly significant interaction for HT, while in Hungary $M \times G$ was significant for SY and slightly significant for WG. Based on the three trial years, there were no significant differences in the performance of the genotypes at the Austrian site, when the growing conditions were also taken into consideration (Table 4).

Genotypic performance, variance and heritability

The first and second degree statistical data averaged over three years were calculated for the whole trial and for each country and management system separately (Online Resource 3). Using the full REML random model (v), wide variation was observed in the agronomic, morphological and quality traits resulting in genotypic variances $\left(\sigma_{G}^{2}\right)$ significantly larger than zero for 10 traits (all at $\mathrm{P} \leq 0.05$ ), the only exception being grain yield. High repeatability (broad-sense heritability) values $\left(0.88<h^{2}\right)$ were also obtained for the 10 traits, suggesting that they were highly dependent on the genotype. Only grain yield showed relatively low broad-sense heritability $\left(h^{2}=0.569\right)$. Similar results were found using the split model (vi).

Averaged over years, countries and genotypes, winter durum genotypes were taller, yielded more, headed slightly later, had higher gluten index, protein and wet gluten contents and slightly better yellow index values 
under conventional growing conditions, while the physical parameters of the grain (TGW and GD) and consequently the semolina yield of the organic samples were slightly higher. In general, genotypes grown in the French location gave lower grain yield, headed earlier and had lower protein and wet gluten contents than in the other countries, while the highest protein and wet gluten contents were found in Hungary irrespective of the management system. In conventional fields the grain yield was the highest in Hungary (5.29 t/ha), while the Austrian location gave the highest yield (4.38 t/ha) under organic growing conditions (Online Resource 3).

\section{Correlations between traits}

Pair-wise correlations between the 11 traits were mostly similar in both management systems (Online Resource 4). In most cases, due to the large number of data pairs, the correlations demonstrated with the phenotypic correlation coefficient $\left(r_{P}\right)$ were significant $(\mathrm{P} \leq 0.05)$, even if their strength was weak $\left(r_{P}<0.4\right)$. Very strong $\left(r_{P}\right.$ $\geq 0.8$ : HT, GP, WG, GI, GL, YI) or strong $\left(0.8>r_{P} \geq 0.6\right.$ : GY, PH, TGW, GD) positive correlations were found between the management systems for most traits, but the linkage was moderate for SY (Online Resource 4, diagonal).

In both management systems, a very strong significant positive correlation was found between GP and WG. At the same time, GP had a strong or moderate negative correlation with GY in conventional and organic fields, respectively, while its negative correlation with $\mathrm{PH}$ was strong in organic and moderate in conventional fields. Gluten index had a moderate negative correlation with WG, but a weak negative correlation with GP. SY was also negatively correlated with GP and WG, but showed a positive correlation with TGW and GD (moderate in $\mathrm{C}$ and weak in O), and a weak negative correlation with GL in both management systems (Online Resource 4).

\section{Discussion}

\section{Selection site}

Based on the results generated by the GGE biplot analysis, possible selection site - trait combinations for winter durum breeding were identified for 11 agronomic and technological quality traits (Table 3). Nevertheless, interactions between the genotype and location $(L \times G)$ or management system $(M \times G)$ had to be further examined to determine traits where selection could result in different outcomes when carried out under different growing conditions (country or management). Environment-targeted selection methods are of great importance in organic breeding, because the environmental conditions have a substantial effect on quantitatively inherited traits, especially under stress-prone conditions. If a stress environment is defined as one resulting in limited plant productivity due to either nutritional (Ceccarelli 1996) or biotic stress factors (pathogens, pests and/or weeds; Murphy et al. 2005; Bàrberi 2002), the organic production system can be classified as this type. The response to different malnutrition and biotic stress factors may be even more pronounced under sub-optimal climatic conditions (Atkinson and Urwin 2012).

Besides the strong genotypic effect, the trial location (country) also had a significant influence on 10 of the traits tested, unlike grain yield which showed only a management-specific main effect. Based on the non-significant $L \times G$ interactions, the tested genotypes responded very similarly to the changes, irrespective of the different countries, in the case of GY, PH, SY and WG (Table 4). According to the stratification map developed by Metzger et al. (2005), the trial sites (C and O) in Austria and Hungary were in the Pannonian Environmental 
Zone, while those established in France were in the South Mediterranean Environmental Zone. The target area of winter durum wheat production is mainly located in the Black Sea and Caspian Sea region, ranging in practice from Hungary to Azerbaijan (Palamarchuk 2005). Since winter durum is produced on $25 \%$ of the durum growing area in Austria (Lafferty 2011) and there are active breeding programmes in Germany, the two latter countries also belong to the group of countries where this crop is of importance. By contrast, France is not a typical winter durum growing environment, as also indicated by this study. Due to the lower latitude and warmer climate conditions in France, the optimal vegetative period was too short for winter durum varieties. In this case, limitations were imposed by the climate (Bunting 1975), leading to reduced dry matter accumulation and finally to weaker performance, resulting in its differentiation as a distinct mega-environment, e.g. in the case of SY, YI and GI (Online Resource 2).

In the search for the ideal winter durum breeding site, the GGE biplot and the REML analyses revealed that the Hungarian trial location (especially the conventional site) could be the most appropriate for selecting both specifically and generally adapted genotypes with regard to traits with significant $L \times G$ interactions (Table 3 and Table 4). The French trial location could be another good choice, but as it is in another Environmental Zone, it should be considered separately. It should also be emphasised that winter hardiness was not among the traits examined, so the French site could only be used for selection of winter durum breeding lines previously selected for winter hardiness in an appropriate environment. Besides the Hungarian trial location, the Austrian location could be used in selection for HT and physical grain parameters (Table 3). Based on the results of the REML analysis, $M \times G$ and $L \times G$ interactions for GP were only found to be significant in France and in conventional fields, respectively. Therefore, selection for GP in those environments could result in locally adapted breeding lines of winter durum wheat (e.g. organic vs. conventional fields in France, or conventional cultivation in different countries). The results also suggest that winter durum genotypes should be selected for SY and GI specifically in the target country and mega-environment, respectively (Online Resource 2). Although the management systems were not found to influence grain yield (and the correlation between the management systems was strong), significant differences were found between the organic fields located in the different countries, suggesting the need for environmentally targeted selection for grain yield in organic fields (Table 4).

\section{Genotype performance and selection target}

In organic agriculture, where synthetic pesticides and fertilizers are not applied, genetic variation is the primary mechanism for buffering environmental fluctuations and maintaining important traits and adaptation to low soil fertility (Murphy et al. 2005). In the present study 14 winter durum varieties with different geographical origins and breeding histories were tested simultaneously in conventional and organic fields. The ideal genotypes (high performance and stability) for GY, PH, TGW, GD, GL, GI and YI were Austrian ones, while ideal varieties for most technological quality traits were selected in Hungary (Table 3). In addition, heading time of the French varieties was the earliest, which is a clear consequence of selection, as earliness is very important to escape postheading heat stress (Pecetti and Annicchiarico 1998).

The genotypes responded very similarly to the changes, irrespective of the management system (non-significant $M \times G$ interactions), except for $\mathrm{HT}, \mathrm{WG}$ and SY, meaning that selection for these traits in organic fields could result in different, more adequate phenotypes, as selection was made in conventional fields. However, it should be noted that only the main effect of country was significant for HT and SY, whereas a significant management 
effect was only found for SY within the separate countries and for HT only in Austria and France (Table 4). Regarding heading time, genotype had a stronger effect than the interaction, as was also demonstrated by the very strong positive correlation between the management systems (Online Resource 4) and by previous studies (Longin et al. 2013; Vida et al. 2014). The present results suggest that organic-targeted selection for these traits could only be effectively carried out within the given country. In this regard, the traits that could be effectively selected in organic fields and presumably also in low input fields are WG and SY in Hungary and HT, WG and GP in France. No significant $M \times G$ interactions were found in Austria, which could be the result of the lower environmental variability within the country, probably due to the better conditions of organic fields (more rain and higher humus content) than in the other countries (Online Resource 1). The difference between the rate of divergence between organic and conventional sites in Austria compared to Hungary also supports this finding for most of the traits (Online Resource 2).

Previously published results on agronomic (Mikó et al. 2014) and quality (Rakszegi et al. 2016) traits of bread wheat under conventional and organic conditions at the same sites in Austria and Hungary during the same period (2011-2013) revealed significant $M \times G$ interactions for GY and GI and for one quality and five other agronomic traits not assessed in the present trial. The deviation between the results achieved for winter bread and durum wheat was presumably due to the different genetic background of the populations tested. In the bread wheat experiment 37 varieties with three different breeding origins (conventional, organic and combined) and a wide genetic basis were studied, whereas the genetic background was narrower in the winter durum set (Table 1). The genetic diversity in bread wheat is thought to be larger (Barrett et al. 1998; Reif et al. 2005) than in durum (Autrique et al. 1996; Soleimani et al. 2002), and this is particularly true for the winter durum gene pool, where the number of available sources is more limited.

The repeatability (broad-sense heritability: $h^{2}$ ) values were very high for all traits except GY. These results were in line with earlier studies (Longin et al. 2013; Vida et al. 2014) in the case of GI, YI, HT and PH, but two other growing season-dependent traits (WG and GP) were less heritable in studies performed in earlier years and in conventional fields with diverse inputs. These different findings could be due to the much higher number and variability of durum genotypes used in those studies and/or to different year effects in the experiments, expressed as lower phenotypic variance in the present work. Nevertheless, successful selection can be carried out on winter durum in early generations under any type of growing conditions for these four traits separately in each country or mega-environment. It must not be forgotten, however, that selecting for WG and GP in different management systems could result in different breeding lines, as in the case of SY, which was also reflected in the moderate correlation $\left(r_{P}=0.45^{* * *}\right.$ ) between the two management systems (Online Resource 4).

Heritability was lower for grain yield, showing the importance of selection for high-yielding genotypes in later generations and in target environments. Le Gouis et al. (2000) and Saulescu et al. (2005) proposed simultaneous selection under diverse input regimes in order to favour varieties for low input and also for organic management systems. In this type of breeding system the first step is to select the material for highly heritable traits in early generations in conventional fields, after which selection should be carried out under organic or low input growing conditions for less heritable traits that also exhibit significant $M \times G$ interactions, as demonstrated in the present study and in many other studies (Oberforster et al. 2003; Löschenberger et al. 2008; Przystalski et al. 2008; Wolfe et al. 2008; Baenziger et al. 2011; Mikó et al. 2014). Based on the present results, WG, GP, SY and 
GY could be among the secondary selection targets that should be worked on under special (organic or low input) growing conditions.

Based on the significant phenotypic correlations, selecting for wet gluten content and semolina yield could be effective in organic selection for GP $\left(r_{P}=0.89 * * *\right)$ and TGW $\left(r_{P}=0.15^{* *}\right)$, respectively. The GP of winter durum exhibited significant, strong or moderate negative linkage with grain yield $\left(\mathrm{C}: r_{P}=-0.69 * * * ; 0: r_{P}=-\right.$ $0.46^{* * *}$ ), as also demonstrated previously by Longin et al. (2013), who reported a slightly weaker correlation. Since a strong negative correlation was found between GP and PH and the latter trait plays an important role in competing against weeds (Gooding et al. 1993; Mason and Spaner 2006), a compromise plant height should be targeted during selection, considering that taller varieties are needed in sub-optimal environments (like organic or low input conventional fields) due to the lack of nutritional resources (Wolfe et al. 2008). This was not the case for the set of winter durum genotypes used in the present study, because no significant $M \times G$ interaction was found for plant height, probably due to the similar genetic backgrounds for PH in this plant material.

Both management systems showed good wet gluten content (over 34\%) and very good gluten strength (GI>78; Cubbada et al. 1992). A moderate negative correlation between WG and GI was reported earlier by Peña (2000) in spring durum, and by Vida et al. (2014) in a set of winter durum genotypes with a relatively wide genetic background. The correlations were even stronger in the present set of genotypes as the $r_{p}$ values were $-0.53^{* * *}$ and $-0.46^{* * *}$ under conventional and organic conditions, respectively. This could be explained by the higher ratio of extreme genotypes (i.e. high WG combined with low GI in Mv Makaróni, or low WG with high GI in Troubadur, Lupidur and Logidur).

Besides GY, GP, WG and SY, the yellow index is also an important trait in durum production (Troccoli et al. 2000), but the mean yellow index of most of the genotypes in both management systems was lower than required by the pasta industry in Europe (Pollini et al. 2012). This could be explained by the fact that the durum samples were milled on a laboratory mill where particle size and distribution and bran ratio differed slightly from those produced by industrial mills; consequently, the reflected light of the Minolta CR-300 instrument generated a lower $b^{*}$-value.

\section{Prospects for organic winter durum breeding}

The most important goal of this study was to determine selection targets, locations and methods for organic (and low input) agriculture based on the performance of diverse winter durum genotypes. There was no organically bred variety among the genotypes tested, so this point of reference was missing from the experiment and the evaluation. Such varieties might perform much better under organic conditions. Nevertheless, the clear effect of the selection environment on the performance of the varieties was demonstrated in the present study, as the varieties with the best performance were those selected in their native mega-environment, except in the case of yellow index, which was found to be affected to a greater extent by the genotype itself (Table 3 ), as previously reported by Vida et al. (2014). This indicates the great influence of the selection environment (whether it be management system or growing region) on the traits of winter durum breeding lines, as proved in the present study for WG, GP, HT and SY and indirectly for GY, GI and PH.

One more thing should be considered: organic farming system is a holistic approach. Organic cereals are not only important for feed and food, but also for their contribution to good soil structure and soil fertility (Wolfe et al. 2008). In addition, genotypes with better nitrogen-use efficiency, rhizosphere competence for disease 
suppression, weed competition, tolerance to mechanical weed control, resistance to pathogens/pests and tolerance to abiotic stress factors would be ideal for both organic and low input farming systems (Lammerts van Bueren et al. 2010). Although the picture is less clear than for bread wheat, the results could encourage the development and spread of organic (winter) durum breeding, which could be further improved by including specific traits of organic agriculture (e.g. leaf inclination, soil coverage at different growth stages and plant vigour) in the selection system. Nevertheless, the economic viability of organic winter durum breeding is questionable, since winter durum has only a small place in overall durum improvement. It is less important than the breeding of bread wheat, so the economic sustainability should be analysed before starting separate selection work for organic agriculture.

\section{References}

Atkinson NJ, Urwin PE (2012) The interaction of plant biotic and abiotic stresses: from genes to the field. J Exp Bot 63:3523-3543

Autrique E, Nachit MM, Monneveux P, Tanksley SD, Sorrells ME (1996) Genetic diversity in durum wheat based on RFLPs, morphophysiological traits, and coefficient of parentage. Crop Sci 36:735-742

Baenziger PS, Salah I, Little RS, Santra DK, Regassa T, Wang MY (2011) Structuring an efficient organic wheat breeding program. Sustainability 3:1190-1205

Bàrberi P (2002) Weed management in organic agriculture: Are we addressing the right issues? Weed Res 42:177-193

Barrett BA, Kidwell KK, Fox PN (1998) Comparison of AFLP and pedigree-based genetic diversity assessment methods using wheat cultivars from the Pacific Northwest. Crop Sci 38:1271-1278

Bunting AH (1975) Time, phenology and the yields of crops. Weather 30:312-325

Ceccarelli S (1996) Adaptation to low/high input cultivation. Euphytica 92:203-214

Cubbada R, Carcea M, Pasqui LA (1992) Suitability of the gluten index method for assessing gluten strength in durum wheat and semolina. Cereal Food World 37:866-869

Dinelli G, Di Silvestro R, Marotti I, Bosi S, Bregola V, Di Loreto A, Nipoti P, Prodi A, Catizone P (2014) Agronomic traits and deoxynivalenol contamination of two tetraploid wheat species (Triticum turgidum spp. durum, Triticum turgidum spp. turanicum) grown strictly under low input conditions. Ital J Agronomy 9:127-135

Dinelli G, Marotti I, Di Silvestro R, Bosi S, Bregola V, Accorsi M, Di Loreto A, Benedettelli S, Ghiselli L, Catizone P (2013) Agronomic, nutritional and nutraceutical aspects of durum wheat (Triticum durum Desf.) cultivars under low input agricultural management. Ital J Agronomy 8:85-93

Evans JD (1996) Straightforward statistics for the behavioral sciences. Brooks/Cole Publishing, Pacific Grove (CA), USA, 624pp 
Fagnano M, Fiorentino N, D’Egidio MG, Quaranta F, Ritieni A, Ferracane R, Raimondi G (2012) Durum wheat in conventional and organic farming: Yield amount and pasta quality in southern Italy. The Scientific World Journal Volume 2012, Article ID 973058, 9pp. doi:10.1100/2012/973058

Giambalvo D, Ruisi P, Di Miceli G, Frenda AS, Amato G (2010) Nitrogen use efficiency and nitrogen fertilizer recovery of durum wheat genotypes as affected by interspecific competition. Agronomy J 102:709-715

Gooding MJ, Thompson AJ, Davies WP (1993) Interception of photosynthetically active radiation, competitive ability and yield of organically grown wheat varieties. Aspects Appl Biol 34:355-362

Lafferty J (2011) Durum - zwischen Ertrag und Qualität? 61. Tagung der Vereinigung der Pflanzenzüchter und Saatgutkaufleute Österreichs 2010, 41-44

Lammerts van Bueren ET, Jones SS, Tamm L, Murphy KM, Myers JR, Leifert C, Messmer MM (2010) The need to breed crop varieties suitable for organic farming, using wheat, tomato and broccoli as examples: a review. NJAS Wageningen J Life Sci 58:193-205

Le Gouis J, Béghin D, Heumez E, Pluchard P (2000) Genetic differences for nitrogen uptake and nitrogen utilisation efficiencies in winter wheat. Eur J Agron 12:163-173

Longin CFH, Sieber A-N, Reif JC (2013) Combining frost tolerance, high grain yield and good pasta quality in durum wheat. Plant Breeding 132:353-358

Löschenberger F, Fleck A, Grausgruber H, Hetzendorfer H, Hof G, Lafferty J, Marn M, Neumayer A, Pfaffinger G, Birschitzky J (2008) Breeding for organic agriculture: The example of winter wheat in Austria. Euphytica 163:469-480

Mason HE, Spaner D (2006) Competitive ability of wheat in conventional and organic management systems: A review of the literature. Can J Plant Sci 86:333-343

Melchinger AE, Utz HF, Schön CC (1998) Quantitative trait locus (QTL) mapping using different testers and independent population samples in maize reveals low power of QTL detection and large bias in estimates of QTL effects. Genetics 149:383-403

Metzger MJ, Bunce RGH, Jongman RHG, Mücher CA, Watkins JW (2005) A climatic stratification of the environment of Europe. Global Ecol Biogeogr 14:549-563

Mikó P, Löschenberger F, Hiltbrunner J, Aebi R, Megyeri M, Kovács G, Molnár-Láng M, Vida G, Rakszegi M (2014) Comparison of bread wheat varieties with different breeding origin under organic and low input management. Euphytica 199:69-80

Murphy KM, Campbell KG, Lyon SR, Jones SS (2007) Evidence of varietal adaptation to organic farming systems. Field Crops Res 102:172-177

Murphy K, Lammer D, Lyon S, Carter B, Jones SS (2005) Breeding for organic and low-input farming systems: an evolutionary-participatory breeding method for inbred cereal grains. Renew Agric Food Syst 20:48-55

Nuijten E, Messmer MM, Lammerts van Bueren ET (2017) Concepts and strategies of organic plant breeding in light of novel breeding techniques. Sustainability 9:18. doi:10.3390/su9010018 
Oberforster M (2003) Verfahren der Wertprüfung für den ökologischen Landbau in Österreich. In: Bundessortenamt (ed) Sortenwertprüfungen für den ökologischen Landbau, Workshop, May 14-15, Hannover, Germany, pp20-27

Palamarchuk A (2005) Selection strategies for traits relevant for winter and facultative durum wheat. In: Royo C, Nachit M, Di Fonzo N, Araus JL, Pfeiffer WH, Slafer GA (eds) Durum wheat breeding: current approaches and future strategies. Food Products Press, New York, USA, pp599-644

Pecetti L, Annicchiarico P (1998) Agronomic value and plant type of Italian durum wheat cultivars from different eras of breeding. Euphytica 99:9-15

Peña RJ (2000) Durum wheat for pasta and bread-making. Comparison of methods used in breeding to determine gluten quality-related parameters. In: Royo C, Nachit MM, Di Fonzo N, Araus JL (eds) Durum wheat improvement in the Mediterranean region: new challenges. Options Méditerranéennes Série A 40:423-430

Pollini CM, Panto F, Nespoli A, Sissons M, Abecassis J (2012) Manufacture of pasta products. In: Sissons M, Abecassis J, Marchylo B, Carcea M (eds) Durum Wheat Chemistry and Technology, 2nd edition, American Association of Cereal Chemists International, St. Paul (MN), USA, pp 161-176

Przystalski M, Osman A, Thiemt EM, Rolland B, Ericson L, Østergard H, Levy L, Wolfe M, Büchse A, Piepho H-P, Krajewski P (2008) Comparing the performance of cereal varieties in organic and non-organic cropping systems in different European countries. Euphytica 163:417-433

Rakszegi M, Mikó P, Löschenberger F, Hiltbrunner J, Aebi R, Knapp S, Tremmel-Bede K, Megyeri M, Kovács G, Molnár-Láng M, Vida G, Láng L, Bedő Z (2016) Comparison of quality parameters of wheat varieties with different breeding origin under organic and low-input conventional conditions. J Cereal Sci 69:297-305

Reif JC, Zhang P, Dreisigacker S, Warburton ML, van Ginkel M, Hoisington D, Bohn M, Melchinger AM (2005) Wheat genetic diversity trends during domestication and breeding. Theor Appl Genet 110:859-864

Saulescu NN, Ittu G, Mustatea P, Simion G (2005) Improved nitrogen response as an objective in wheat breeding. Romanian Agric Res 22:1-4

Soleimani VD, Baum BR, Johnson DA (2002) AFLP and pedigree-based genetic diversity estimates in modern cultivars of durum wheat [Triticum turgidum L. subsp. durum (Desf.) Husn.]. Theor Appl Genet 104:350357

Stagnari F, Onofri A, Codianni P, Pisante M (2013) Durum wheat varieties in N-deficient environments and organic farming: a comparison of yield, quality and stability performances. Plant Breeding 132:266-275

Troccoli A, Borrelli GM, De Vita P, Fares C, Di Fonzo N (2000) Durum wheat quality: a multidisciplinary concept. J Cereal Sci 32:99-113

Vida G, Szunics L, Veisz O, Bedő Z, Láng L, Árendás T, Bónis P, Rakszegi M (2014) Effect of genotypic, meteorological and agronomic factors on the gluten index of winter durum wheat. Euphytica 197:61-71

Virk DS, Pandit DB, Sufian MA, Ahmed F, Siddique MAB, Samad MA, Rahman MM, Islam MM, Ortiz-Ferrara G, Joshi KD, Withcombe JR (2009) REML is an effective analysis for mixed modelling of unbalanced onfarm varietal trials. Expl Agric 45:77-91 
Wolfe MS, Baresel JP, Desclaux D, Goldringer I, Hoad S, Kovács G, Löschenberger F, Miedaner T, Østergard H, Lammerts van Bueren ET (2008) Developments in breeding cereals for organic agriculture. Euphytica $163: 323-346$

Yan W, Tinker NA (2006) Biplot analysis of multi-environment trial data: Principles and applications. Can J Plant Sci 86:623-645

\section{Captions}

Online Resource 1 Geographical, meteorological, soil and growing conditions at the winter durum wheat trial locations in Austria (A), France (F) and Hungary (H) in 2010-2013

Online Resource 2 The which-won-where view and test environment ranking view (ideal test environment is represented by the centre of the concentric circles) of the GGE biplot analysis for 11 traits based on the performance of 14 winter durum genotypes examined in Austria (A), France (F) and Hungary $(\mathrm{H})$ under conventional (C) and organic (O) growing conditions (6 trial sites: AC, AO, FC, FO, HC, HO) between 2011 and 2013

Online Resource 3 Mean with standard deviation (std), minimum and maximum values and the corresponding variance components with broad-sense heritability of 14 winter durum wheat varieties and breeding lines tested for 11 traits in Austria (A), France $(\mathrm{F})$ and Hungary $(\mathrm{H})$ under conventional and organic growing conditions between 2011 and 2013

Online Resource 4 Phenotypic correlation coefficients $\left(r_{p}\right)$ between the best linear unbiased estimators (BLUEs) among the data of 14 winter durum wheat genotypes grown under organic (below diagonal) and conventional (above diagonal) field conditions, evaluated for 11 agronomic, phenotypic and technological quality traits assessed in Austria, France and Hungary in the period 2011-2013 
Table 1 Pedigree and origin of winter durum wheat genotypes tested in conventional and organic field experiments at trial locations in Austria (A), France (F) and Hungary (H) between 2011 and 2013 (D refers to Germany)

\begin{tabular}{lll}
\hline \multicolumn{1}{c}{ Genotype } & \multicolumn{1}{c}{ Pedigree } & Breeder, city (country) \\
\hline Mv Makaróni & GK Tiszadur/Chernomor & ATK, Martonvásár (H) \\
Mv Pennedur & GKD75/Aisberg//GK Bétadur & ATK, Martonvásár (H) \\
Mv Hundur & GK Bétadur/Aisberg & ATK, Martonvásár (H) \\
MvTD07-09 & MVTD22-99/SOD168 & ATK, Martonvásár (H) \\
Lunadur & MVTD29-94/Superdur & SZD, Linz (A) \\
Logidur & GK Novodur/Superdur & SZD, Probstdorf (A) \\
Lupidur & Prowidur//MvTD29-94/ Superdur//Soldur & SZD, Linz (A) \\
Troubadur & GK Tiszadur/Prowidur//Heradur & SZD, Probstdorf (A) \\
Kiradur & Inverdur/SD5826 & SZD, Probstdorf (A) \\
Cliodur & Prowidur/Superdur & SZD, Linz (A) \\
Wintergold & Lloyd/(92/04/06) & SWS, Rastatt (D) \\
HOH6012 (6.012/03/01) & AC Navigator//Primadur/ Zaporozhskaja & UHL, Hohenheim (D) \\
LA1823 & 2151.5.7/C.44 & INRA, Mauguio (F) \\
YA3445 & 521.6.4/Mondur & INRA, Mauguio (F) \\
\hline
\end{tabular}

Note: ATK, Centre for Agricultural Research, Hungarian Academy of Sciences; SZD, Saatzucht Donau GmbH; SWS, Südwestdeutsche Saatzucht GmbH; UHL, Universität Hohenheim, Landessaatzuchtanstalt; INRA, Institute National de la Recherche Agronomique 
Table 2 Agronomic and quality traits assessed and number of observations in winter durum trials grown under conventional (C) and organic (O) conditions in Austria (A), France (F) and Hungary (H) between 2011 and 2013

\begin{tabular}{|c|c|c|c|c|c|c|c|c|}
\hline \multirow{2}{*}{$\begin{array}{l}\text { Trait } \\
\text { (value or score) }\end{array}$} & \multirow{2}{*}{$\begin{array}{c}\mathrm{Abb} \\
\text { revia } \\
\text { tion }\end{array}$} & \multirow{2}{*}{$\begin{array}{c}\text { Implemen } \\
\text { tation of } \\
\text { measurement or } \\
\text { scoring }\end{array}$} & \multicolumn{3}{|c|}{$\begin{array}{l}\text { Number of replications assessed per location } \\
\text { (conventional/organic) }\end{array}$} & \multicolumn{3}{|c|}{ Total number of } \\
\hline & & & 2011 & 2012 & 2013 & $\begin{array}{l}\text { Envi } \\
\text { ron } \\
\text { ments }\end{array}$ & $\begin{array}{l}\text { Repli } \\
\text { cates } \\
(\mathrm{C} / \mathrm{O})\end{array}$ & $\begin{array}{c}\text { Obser } \\
\text { vations } \\
(\mathrm{C} / \mathrm{O})\end{array}$ \\
\hline Grain yield (t/ha) & GY & $\begin{array}{l}\text { Harvested at } \\
\text { full maturity }\end{array}$ & $\begin{array}{l}\mathrm{A}(3 / 3) \\
\mathrm{H}(3 / 3)\end{array}$ & $\frac{\mathrm{A}(3 / 3)}{\underline{\mathrm{H}(3 / 3)}}, \frac{\mathrm{F}(3 / 3)}{}$ & $\begin{array}{c}\mathrm{A}(3 / 3), \underline{F(3 / 3)} \\
\underline{H(3 / 3)}\end{array}$ & 8 & $24 / 24$ & $312 / 318$ \\
\hline Heading time (day) & HT & $\begin{array}{l}\text { Number of days } \\
\text { after } 30^{\text {th }} \text { April }\end{array}$ & $\begin{array}{l}\mathrm{A}(3 / 3) \\
\mathrm{H}(1 / 1)\end{array}$ & $\begin{array}{c}\mathrm{A}(3 / 3), \mathrm{F}(3 / 3) \\
\mathrm{H}(1 / 1)\end{array}$ & $\begin{array}{l}\mathrm{A}(3 / 3), \mathrm{F}(3 / 3) \\
\mathrm{H}(1 / 1)\end{array}$ & 8 & $18 / 18$ & $232 / 234$ \\
\hline Plant height $(\mathrm{cm})$ & PH & $\begin{array}{l}\text { From ground to } \\
\text { top of canopy }\end{array}$ & $\begin{array}{l}\mathrm{A}(3 / 3) \\
\mathrm{H}(3 / 3)\end{array}$ & $\mathrm{A}(1 / 0), \mathrm{H}(3 / 3)$ & $\begin{array}{l}\mathrm{A}(1 / 3), \mathrm{F}(3 / 3) \\
\mathrm{H}(3 / 3)\end{array}$ & 7 & $17 / 18$ & $220 / 240$ \\
\hline $\begin{array}{l}\text { Grain protein } \\
\text { content }(\%)\end{array}$ & GP & $\begin{array}{c}\text { Kjeldahl } \\
\text { method, Kjeltec } \\
1035\end{array}$ & $\begin{array}{l}\mathrm{A}(1 / 1) \\
\underline{H(3 / 3)}\end{array}$ & $\begin{array}{l}\mathrm{A}(1 / 1), F(3 / 3) \\
\mathrm{H}(3 / 3)\end{array}$ & $\begin{array}{l}\mathrm{A}(1 / 1), \mathrm{F}(3 / 3) \\
\mathrm{H}(1 / 1)\end{array}$ & 8 & $16 / 16$ & $206 / 212$ \\
\hline Semolina yield (\%) & SY & $\begin{array}{l}\text { Chopin CD2 } \\
\text { mill + Purifier }\end{array}$ & $\begin{array}{l}\mathrm{A}(1 / 1) \\
\underline{H(3 / 3)}\end{array}$ & $\begin{array}{c}\mathrm{A}(1 / 1), \mathrm{F}(3 / 3) \\
\mathrm{H}(3 / 3)\end{array}$ & $\begin{array}{l}A(1 / 1), \mathrm{F}(3 / 3) \\
\mathrm{H}(1 / 1)\end{array}$ & 8 & $16 / 16$ & $206 / 212$ \\
\hline $\begin{array}{l}\text { Wet gluten content } \\
(\%)\end{array}$ & WG & $\begin{array}{l}\text { ICC Standard } \\
\text { No. } 158\end{array}$ & $\begin{array}{l}\mathrm{A}(1 / 1), \\
\underline{H(3 / 3)}\end{array}$ & $\begin{array}{c}\mathrm{A}(1 / 1), F(3 / 3), \\
\mathrm{H}(3 / 3)\end{array}$ & $\begin{array}{c}\mathrm{A}(1 / 1), \mathrm{F}(3 / 3), \\
\mathrm{H}(1 / 1)\end{array}$ & 8 & $16 / 16$ & $206 / 212$ \\
\hline $\begin{array}{l}\text { Gluten index } \\
\text { (polymer gluten / } \\
\text { total gluten) }\end{array}$ & GI & $\begin{array}{l}\text { ICC Standard } \\
\text { No. } 158\end{array}$ & $\begin{array}{l}\mathrm{A}(1 / 1) \\
\mathrm{H}(3 / 3)\end{array}$ & $\begin{array}{c}\mathrm{A}(1 / 1), \mathrm{F}(3 / 3), \\
\underline{\mathrm{H}(3 / 3)}\end{array}$ & $\begin{array}{c}\mathrm{A}(1 / 1), \mathrm{F}(3 / 3), \\
\mathrm{H}(1 / 1)\end{array}$ & 8 & $16 / 16$ & $206 / 212$ \\
\hline $\begin{array}{l}\text { Thousand grain } \\
\text { weight }(\mathrm{g})\end{array}$ & TGW & $\begin{array}{l}\text { Marvin Seed } \\
\text { Tester }\end{array}$ & $\frac{\mathrm{A}(1 / 1)}{\underline{H(3 / 3)}}$ & $\begin{array}{c}\mathrm{A}(1 / 1), \underline{\mathrm{F}(3 / 3)}, \\
H(3 / 3)\end{array}$ & $\begin{array}{c}\mathrm{A}(1 / 1), \underline{\mathrm{F}(3 / 3)}, \\
\underline{\mathrm{H}(1 / 1)}\end{array}$ & 8 & $16 / 16$ & $206 / 212$ \\
\hline $\begin{array}{l}\text { Grain diameter } \\
(\mathrm{mm})\end{array}$ & GD & $\begin{array}{l}\text { Marvin Seed } \\
\text { Tester }\end{array}$ & $\begin{array}{l}A(1 / 1) \\
\underline{\mathrm{H}(3 / 3)}\end{array}$ & $\begin{array}{c}\mathrm{A}(1 / 1), \mathrm{F}(3 / 3), \\
\mathrm{H}(3 / 3)\end{array}$ & $\begin{array}{c}A(1 / 1), \mathrm{F}(3 / 3), \\
\mathrm{H}(1 / 1)\end{array}$ & 8 & $16 / 16$ & $206 / 212$ \\
\hline Grain length (mm) & GL & $\begin{array}{l}\text { Marvin Seed } \\
\text { Tester }\end{array}$ & $\begin{array}{l}\mathrm{A}(1 / 1), \\
\underline{\mathrm{H}(3 / 3)}\end{array}$ & $\begin{array}{c}\mathrm{A}(1 / 1), \mathrm{F}(3 / 3), \\
\mathrm{H}(3 / 3)\end{array}$ & $\begin{array}{c}\mathrm{A}(1 / 1), \mathrm{F}(3 / 3), \\
\mathrm{H}(1 / 1)\end{array}$ & 8 & $16 / 16$ & $206 / 212$ \\
\hline $\begin{array}{l}\text { Yellow index } \\
\left(b^{*} \text {-value }\right)\end{array}$ & YI & $\begin{array}{l}\text { Colour of } \\
\text { semolina by } \\
\text { Minolta CR- } \\
300\end{array}$ & $\frac{A(1 / 1)}{\mathrm{H}(3 / 3)}$ & $\begin{array}{c}\mathrm{A}(1 / 1), \mathrm{F}(3 / 3), \\
\mathrm{H}(3 / 3)\end{array}$ & $\begin{array}{c}\mathrm{A}(1 / 1), \mathrm{F}(3 / 3), \\
H(1 / 1)\end{array}$ & 8 & $16 / 16$ & $206 / 212$ \\
\hline
\end{tabular}


Table 3 Summary of the GGE biplot analysis based on 14 winter durum genotypes examined in Austria (A), France $(\mathrm{F})$ and Hungary $(\mathrm{H})$ under conventional $(\mathrm{C})$ and organic $(\mathrm{O})$ conditions $(6$ trial sites: AC, AO, FC, FO, HC, HO) for 11 traits between 2011 and 2013

\begin{tabular}{|c|c|c|c|c|c|}
\hline \multirow[b]{2}{*}{$\begin{array}{c}\text { Trait } \\
\text { (abbreviation) }\end{array}$} & \multirow[b]{2}{*}{$\begin{array}{l}\text { Source of } \\
\text { variation } \\
\text { Total }(\%) \\
(\mathrm{PC} 1+\mathrm{PC} 2)^{+}\end{array}$} & \multicolumn{2}{|c|}{$\begin{array}{l}\text { Three best } \\
\text { trial sites for }\end{array}$} & \multirow[b]{2}{*}{$\begin{array}{l}\text { Three best genotypes } \\
\text { according to performance } \\
\text { and stability* }\end{array}$} & \multirow[b]{2}{*}{$\begin{array}{l}\text { Best performing genotype } \\
\text { within a mega- } \\
\text { environment** } \\
\text { (trial sites forming a mega- } \\
\text { environment) }\end{array}$} \\
\hline & & $\begin{array}{l}\text { Specifically } \\
\text { adapted } \\
\text { genotypes } \\
\text { (discriminative } \\
\text { and non- } \\
\text { representative) }\end{array}$ & $\begin{array}{c}\text { Generally } \\
\text { adapted } \\
\text { genotypes } \\
\text { (discriminative } \\
\text { and representa } \\
\text { tive) }\end{array}$ & & \\
\hline $\begin{array}{l}\text { Grain yield } \\
\text { (GY) }\end{array}$ & $\begin{array}{c}85.58 \\
(62.06+23.52)\end{array}$ & $\mathrm{HC}, \mathrm{AC}, \mathrm{HO}$ & $\mathrm{HO}, \mathrm{AC}, \mathrm{AO}$ & $\begin{array}{l}\text { Lupidur, Troubadur, } \\
\text { Kiradur, }\end{array}$ & $\begin{array}{c}\text { Lupidur }(\mathrm{AC}+\mathrm{AO}+\mathrm{HC}+\mathrm{HO}), \\
\text { YA3445 }(\mathrm{FC}+\mathrm{FO})\end{array}$ \\
\hline $\begin{array}{l}\text { Heading time } \\
\qquad(\mathrm{HT})\end{array}$ & $\begin{array}{c}89.93 \\
(82.18+7.75)\end{array}$ & $\mathrm{FC}, \mathrm{AO}, \mathrm{FO}$ & $\mathrm{HO}, \mathrm{HC}, \mathrm{FO}$ & $\begin{array}{l}\text { LA1823, YA3445, } \\
\text { Mv Hundur }\end{array}$ & \\
\hline $\begin{array}{l}\text { Plant height } \\
(\mathrm{PH})\end{array}$ & $\begin{array}{c}88.9 \\
(70.93+17.98)\end{array}$ & $\mathrm{AC}, \mathrm{HC}, \mathrm{FC}$ & $\mathrm{AC}, \mathrm{HC}, \mathrm{FO}$ & $\begin{array}{l}\text { Troubadur, Lunadur, } \\
\text { Wintergold }\end{array}$ & \\
\hline $\begin{array}{l}\text { Grain protein } \\
\text { content }(\mathrm{GP})\end{array}$ & $\begin{array}{c}87.87 \\
(48.79+39.08)\end{array}$ & $\mathrm{FC}, \mathrm{FO}, \mathrm{HO}$ & $\mathrm{HC}, \mathrm{HO}, \mathrm{FO}$ & $\begin{array}{l}\text { MvTD07-09, Mv Hundur, } \\
\text { Mv Makaróni }\end{array}$ & $\begin{array}{l}\text { HOH6012 (AC+AO), } \\
\text { Mv Hundur }(\mathrm{HO}+\mathrm{FO})\end{array}$ \\
\hline $\begin{array}{c}\text { Semolina } \\
\text { yield }(S Y)\end{array}$ & $\begin{array}{c}84.27 \\
(48.36+35.91)\end{array}$ & $\mathrm{FC}, \mathrm{FO}, \mathrm{HC}$ & $\mathrm{HC}, \mathrm{FO}, \mathrm{FC}$ & $\begin{array}{l}\text { Mv Pennedur, MvTD07-09, } \\
\text { Mv Hundur }\end{array}$ & $\begin{array}{l}\text { HOH6012 }(\mathrm{AC}+\mathrm{AO}), \\
\text { MvTD07-09 (HC+FO), } \\
\text { YA3445 (FC+HO) }\end{array}$ \\
\hline $\begin{array}{l}\text { Wet gluten } \\
\text { content } \\
\text { (WG) }\end{array}$ & $\begin{array}{c}88.25 \\
(48.89+39.36)\end{array}$ & $\mathrm{HO}, \mathrm{HC}, \mathrm{FC}$ & $\mathrm{HC}, \mathrm{HO}, \mathrm{FO}$ & $\begin{array}{l}\text { MvTD07-09, Mv Pennedur, } \\
\text { Mv Makaróni }\end{array}$ & $\begin{array}{l}\text { HOH6012 (AC+AO), } \\
\text { Mv Makaróni (HO), } \\
\text { LA1823 (FC+FO) }\end{array}$ \\
\hline $\begin{array}{l}\text { Gluten index } \\
\text { (GI) }\end{array}$ & $\begin{array}{c}91.63 \\
(6984+21.80)\end{array}$ & $\mathrm{HC}, \mathrm{FO}, \mathrm{FC}$ & $\mathrm{HO}, \mathrm{HC}, \mathrm{FC}$ & Troubadur, Logidur, Lupidur & $\begin{array}{c}\text { Troubadur } \\
(\mathrm{AC}+\mathrm{AO}+\mathrm{HC}+\mathrm{HO})\end{array}$ \\
\hline $\begin{array}{l}\text { Thousand } \\
\text { grain weight } \\
\text { (TGW) }\end{array}$ & $\begin{array}{c}91.06 \\
(58.43+32.63)\end{array}$ & $\mathrm{HC}, \mathrm{FO}, \mathrm{FC}$ & $\mathrm{FC}, \mathrm{FO}, \mathrm{HO}$ & Lunadur, Troubadur, Cliodur & $\begin{array}{l}\text { Lunadur }(\mathrm{AC}+\mathrm{AO}+\mathrm{HC}), \\
\mathrm{LA} 1823(\mathrm{FC}+\mathrm{FO}+\mathrm{HO})\end{array}$ \\
\hline $\begin{array}{c}\text { Grain } \\
\text { diameter (GD) }\end{array}$ & $\begin{array}{c}87.86 \\
(53.35+34.51)\end{array}$ & $\mathrm{HC}, \mathrm{FC}, \mathrm{FO}$ & $\mathrm{FO}, \mathrm{FC}, \mathrm{AC}$ & $\begin{array}{l}\text { Lunadur, Troubadur, } \\
\text { Kiradur }\end{array}$ & Lunadur $(\mathrm{AC}+\mathrm{AO}+\mathrm{HC})$ \\
\hline $\begin{array}{l}\text { Grain length } \\
\quad(\mathrm{GL})\end{array}$ & $\begin{array}{c}87.32 \\
(46.69+40.63)\end{array}$ & $\mathrm{HC}, \mathrm{FC}, \mathrm{FO}$ & $\mathrm{AO}, \mathrm{FC}, \mathrm{HC}$ & $\begin{array}{c}\text { Lunadur, Wintergold, } \\
\text { Cliodur }\end{array}$ & \\
\hline $\begin{array}{l}\text { Yellow index } \\
\text { (YI) }\end{array}$ & $\begin{array}{c}87.51 \\
(58.81+28.70)\end{array}$ & $\mathrm{HC}, \mathrm{FC}, \mathrm{FO}$ & $\mathrm{HC}, \mathrm{HO}, \mathrm{AO}$ & $\begin{array}{l}\text { Kiradur, Cliodur, } \\
\text { Wintergold }\end{array}$ & $\begin{array}{l}\text { HOH6012 }(\mathrm{AC}+\mathrm{AO}), \\
\text { Kiradur }(\mathrm{HC}+\mathrm{HO}), \\
\text { Mv Hundur }(\mathrm{FC}+\mathrm{FO})\end{array}$ \\
\hline
\end{tabular}

Note: ${ }^{+}$Principal components; ${ }^{\dagger}$ Trial sites with the longest environmental vector length and the largest angle with the AverageEnvironment Axis (AEA) presented in descending order; ${ }^{+}$Trial sites with the longest environmental vector length and the smallest angle with AEA (ideal test environment) presented in descending order; *Based on the distance of a respective genotype from an "ideal" genotype located on the AEA, listed in descending order. Apart from the other traits, genotypes having earlier heading (located most distal from the ideal genotype in the negative direction) and ideal plant height (closer to the trial average, the biplot origin) were taken as optimal ones; **Genotypes located on the vertices of the polygon (drawn on genotypes furthest from the biplot origin) that fell in the same polygon sector (defined by the equality lines starting from the biplot origin) as a given mega-environment (HT and PH cannot be evaluated by this method); trial sites that fell in a sector without a polygon vertex are not demonstrated. Enlargeable GGE biplots are provided in Online Resource 2 
Table 4 Significance of chi-squared ( $\mathrm{F}=$ Wald statistic/d.f.) values calculated with linear mixed models $i i$, iii and $i v$ for traits assessed in the ring test of 14 winter durum wheat genotypes in three European countries under organic and conventional growing conditions between 2011 and 2013

\begin{tabular}{|c|c|c|c|c|c|c|c|c|c|}
\hline \multirow{4}{*}{ Trait (abbreviation) } & \multicolumn{4}{|c|}{$\begin{array}{l}\text { Linear mixed model } i i \\
\text { (for trial location effect) }\end{array}$} & \multicolumn{5}{|c|}{$\begin{array}{l}\text { Linear mixed models } i i i \text { and } i v \\
\text { (for management effect) }\end{array}$} \\
\hline & \multicolumn{2}{|c|}{ Full model } & \multicolumn{2}{|c|}{ Split model } & \multicolumn{2}{|c|}{ Full model (iii) } & \multicolumn{3}{|c|}{ Split model (iv) } \\
\hline & Trial & & $\mathrm{L} \times \mathrm{G}$ & & Management & & & $\mathrm{M} \times \mathrm{G}$ & \\
\hline & (L) & $\mathrm{L} \times \mathrm{U}$ & Conventional & Organic & (M) & & Austria & France & Hungary \\
\hline Grain yield $(\mathrm{GY})$ & $\mathrm{ns}^{\#}$ & ns & ns & $*$ & $* * *$ & ns & ns & ns & ns \\
\hline Heading time (HT) & $* * *$ & $*$ & ns & ns & $\mathrm{ns}^{\#}$ & $* * *$ & ns & + & ns \\
\hline Plant height $(\mathrm{PH})$ & $* * *$ & ns & ns & ns & $* * *$ & ns & ns & ns & ns \\
\hline Grain protein content (GP) & $* * *$ & + & $* *$ & ns & $* * *$ & ns & ns & $*$ & ns \\
\hline Semolina yield (SY) & $* * *$ & ns & ns & ns & $\mathrm{ns}^{\#}$ & + & ns & ns & $*$ \\
\hline Wet gluten content (WG) & $* * *$ & ns & ns & ns & $* * *$ & $* * *$ & ns & $* *$ & + \\
\hline Gluten index (GI) & $* * *$ & $* * *$ & $* *$ & $* * *$ & ns & ns & ns & ns & ns \\
\hline $\begin{array}{l}\text { Thousand grain weight } \\
\text { (TGW) }\end{array}$ & $* * *$ & $* *$ & + & $*$ & $* * *$ & ns & ns & ns & ns \\
\hline Grain diameter (GD) & $* * *$ & $* *$ & ns & + & $* * *$ & ns & ns & ns & ns \\
\hline Grain length (GL) & $* * *$ & $* * *$ & $* *$ & $* *$ & $*$ & ns & ns & ns & ns \\
\hline Yellow index (YI) & $* * *$ & $* * *$ & + & + & $* * *$ & ns & ns & ns & ns \\
\hline
\end{tabular}




\section{EUPHYTICA}

\section{Selection of winter durum genotypes grown under conventional and organic conditions in different European regions}

Péter Mikó, Gyula Vida, Marianna Rakszegi*, Julia Lafferty, Bruno Lorentz, Carl Friedrich Horst Longin, Mária Megyeri

*corresponding author: rakszegi.mariann@agrar.mta.hu, Agricultural Institute, Centre for Agricultural Research, Hungarian Academy of Sciences, Brunszvik u. 2, 2462 Martonvásár, Hungary

Online Resource 1 Geographical, meteorological, soil and growing conditions at the winter durum wheat trial locations in Austria (A), France (F) and Hungary (H) in 2010-2013

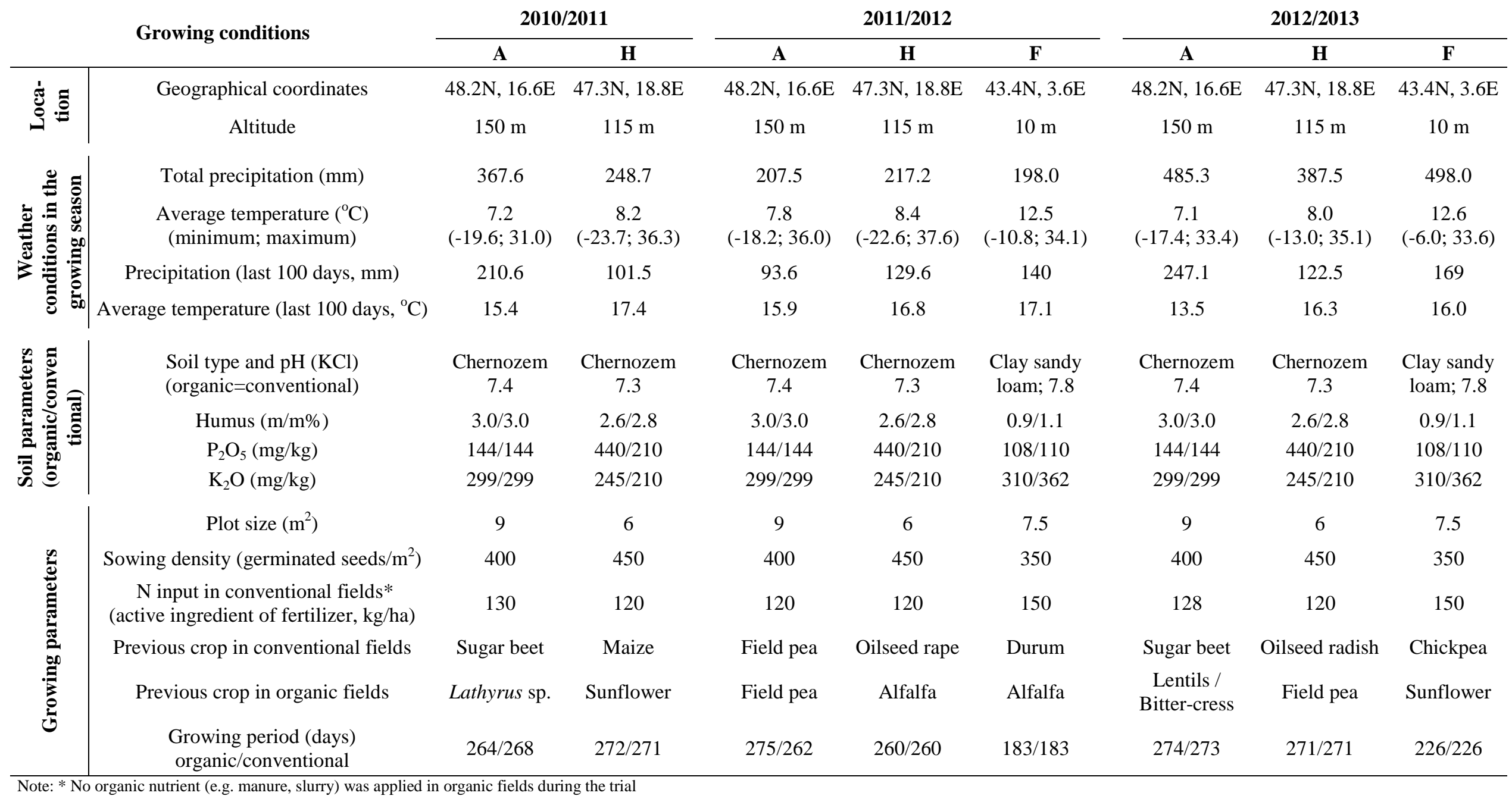


Online Resource 2 The which-won-where view and test environment ranking view (ideal test environment is represented by the centre of the concentric circles) of the GGE biplot analysis for 11 traits based on the performance of 14 winter durum genotypes examined in Austria (A), France $(\mathrm{F})$ and Hungary $(\mathrm{H})$ under conventional $(\mathrm{C})$ and organic $(\mathrm{O})$ growing conditions (6 trial sites: AC, AO, FC, FO, HC, HO) between 2011 and 2013
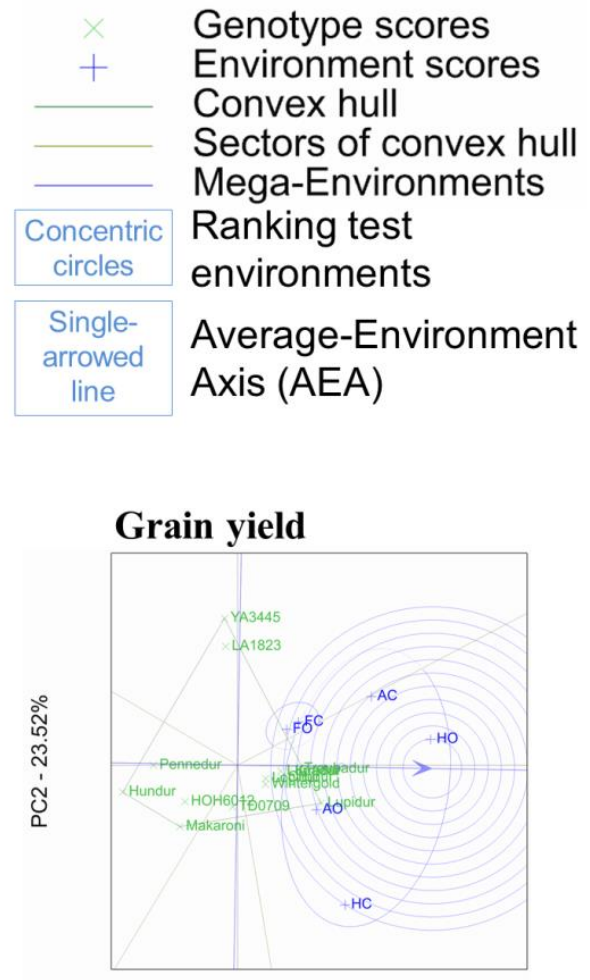

PC1 - 62.06\%

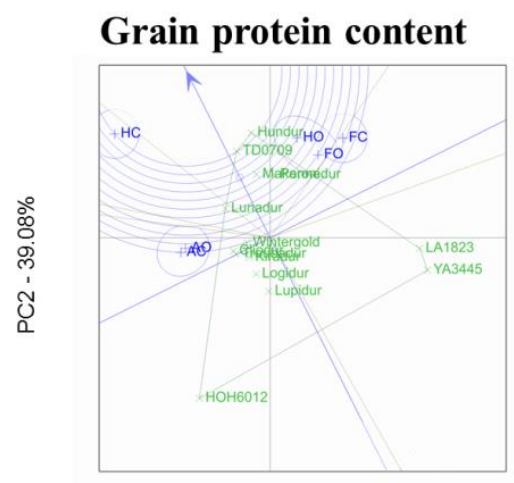

PC1 $-48.79 \%$

\section{Thousand grain weight}

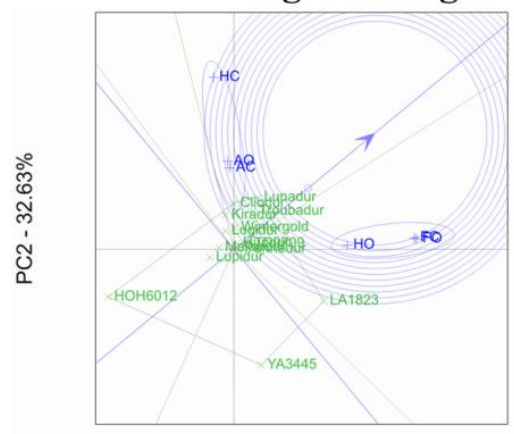

PC1 - 58.43\%

\section{Plant height}

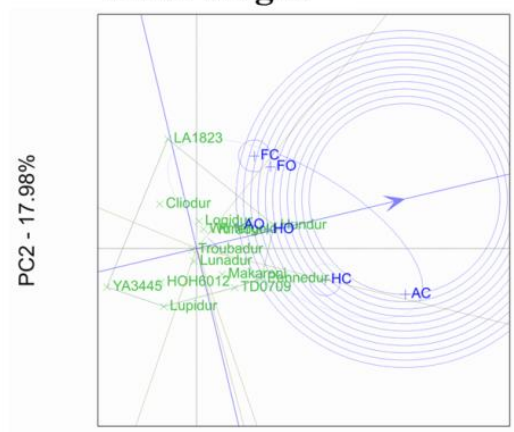

PC1 - $70.93 \%$

\section{Gluten index}

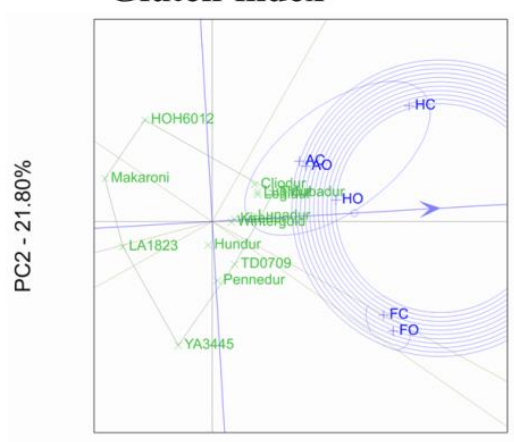

PC1 $-69.84 \%$

\section{Wet gluten content}

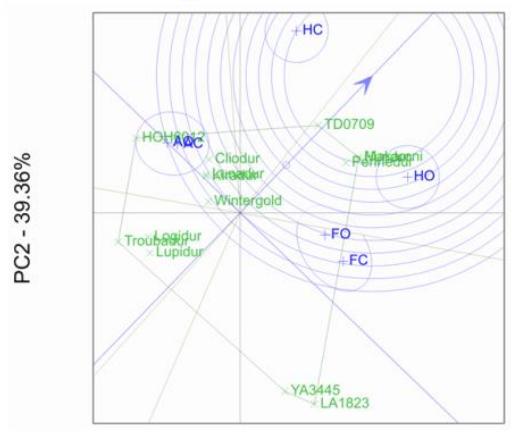

PC1 - 48.89\%

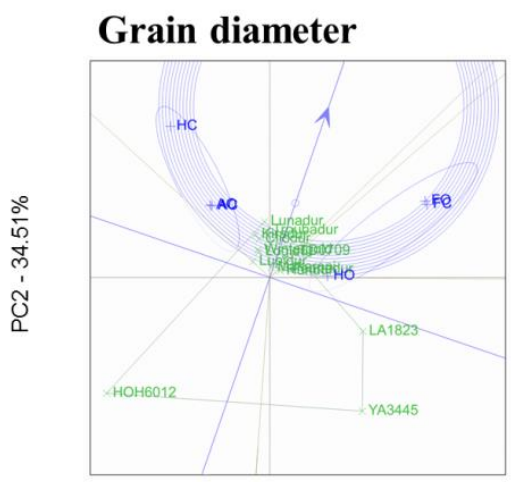

PC1 - 53.35\%

\section{Heading time}

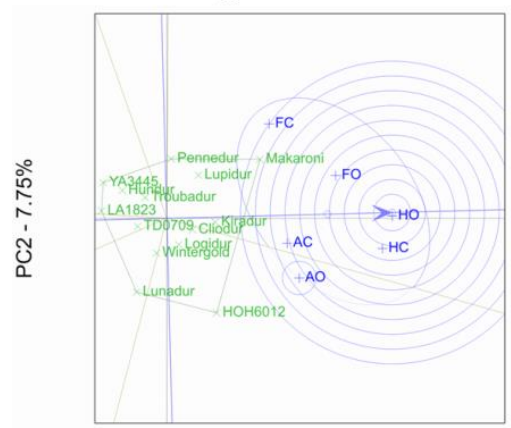

PC1 - 82.18\%

Yellow index

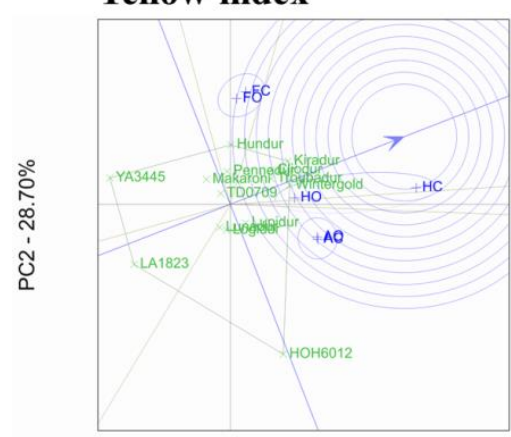

PC1 - 58.81\%

\section{Semolina yield}

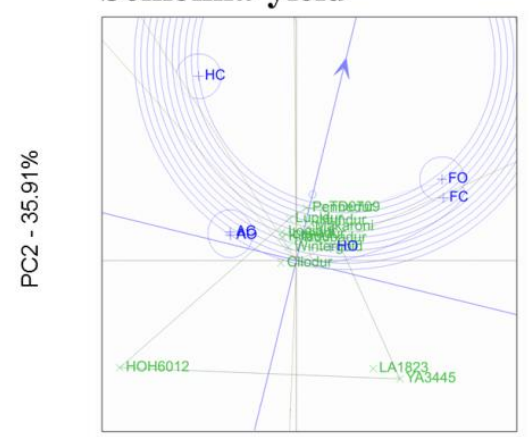

PC1 - 48.36\%

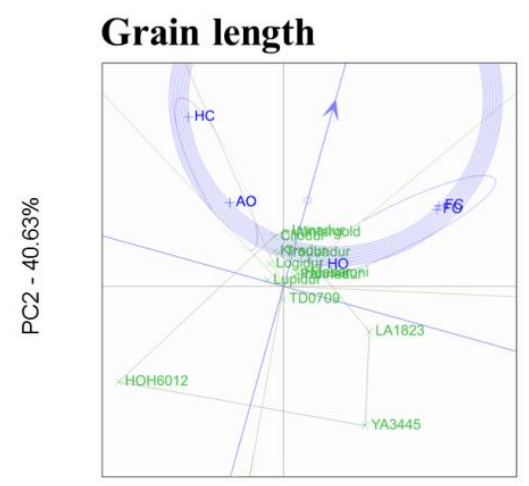

PC1 - 46.69\% 
Online Resource 3 Mean with standard deviation (std), minimum and maximum values and the corresponding variance components with broad-sense heritability of 14 winter durum wheat varieties and breeding lines tested for 11 traits in Austria (A), France (F) and Hungary $(\mathrm{H})$ under conventional and organic growing conditions between 2011 and 2013

\begin{tabular}{|c|c|c|c|c|c|c|c|c|c|c|c|c|c|c|c|c|c|c|}
\hline \multicolumn{3}{|c|}{$\begin{array}{c}\text { Trait measured or } \\
\text { scored (value or } \\
\text { score) }\end{array}$} & $\begin{array}{l}\text { Abbre- } \\
\text { viation }\end{array}$ & $\begin{array}{l}\text { Mean } \\
\pm \text { std }\end{array}$ & $\mathbf{A}$ & $\mathbf{F}$ & $\mathbf{H}$ & Min & Max & $\sigma_{E}^{2}$ & $\sigma_{M}^{2}$ & $\sigma_{G}^{2}$ & $\sigma_{E \times M}^{2}$ & $\sigma_{G \times E}^{2}$ & $\sigma_{G \times M}^{2}$ & $\sigma_{G \times M \times E}^{2}$ & $\sigma_{e}^{2}$ & $h^{2}$ \\
\hline \multicolumn{3}{|c|}{ Grain yield (t/ha) } & GY & $\begin{array}{l}4.35 \\
\pm 2.05\end{array}$ & $\begin{array}{l}4.55 \\
\pm 1.26\end{array}$ & $\begin{array}{c}3.92 \\
\pm 1.06\end{array}$ & $\begin{array}{c}4.48 \\
\pm 2.92\end{array}$ & 0.07 & 9.45 & 1.73 & 0.40 & 0.10 & 1.65 & 0.51 & 0.00 & $\underline{0.08}$ & 0.32 & 0.569 \\
\hline \multicolumn{3}{|c|}{$\begin{array}{l}\text { Heading time (number } \\
\text { of days after } 30^{\text {th }} \text { April) }\end{array}$} & HT & $\begin{array}{l}15.24 \\
\pm 8.03\end{array}$ & $\begin{array}{l}21.83 \\
\pm 2.51\end{array}$ & $\begin{array}{c}5.82 \\
\pm 3.60\end{array}$ & $\begin{array}{l}17.18 \\
\pm 4.80\end{array}$ & 0.50 & 30.00 & 52.17 & 0.00 & 3.55 & 2.21 & $\underline{0.88}$ & 0.17 & 0.82 & 1.17 & 0.927 \\
\hline \multicolumn{3}{|c|}{ Plant height $(\mathrm{cm})$} & PH & $\begin{array}{c}79.73 \\
\pm 15.33\end{array}$ & $\begin{array}{c}79.07 \\
\pm 11.55\end{array}$ & $\begin{array}{l}86.84 \\
\pm 6.52\end{array}$ & $\begin{array}{c}77.65 \\
\pm 18.27\end{array}$ & 40.00 & 118.00 & 136.51 & 2.54 & 13.64 & 79.47 & $\underline{7.18}$ & 0.00 & 4.28 & 16.78 & 0.883 \\
\hline \multicolumn{3}{|c|}{$\begin{array}{l}\text { Grain protein content } \\
(\%)\end{array}$} & GP & $\begin{array}{l}14.06 \\
\pm 3.23\end{array}$ & $\begin{array}{l}13.95 \\
\pm 1.88\end{array}$ & $\begin{array}{l}12.77 \\
\pm 2.83\end{array}$ & $\begin{array}{l}15.21 \\
\pm 3.49\end{array}$ & 7.90 & 23.10 & 5.84 & 0.20 & 0.82 & 1.19 & 0.47 & 0.00 & 0.24 & 0.37 & 0.906 \\
\hline \multicolumn{3}{|c|}{ Semolina yield (\%) } & SY & $\begin{array}{l}43.29 \\
\pm 3.67\end{array}$ & $\begin{array}{l}43.09 \\
\pm 2.98\end{array}$ & $\begin{array}{l}43.80 \\
\pm 4.03\end{array}$ & $\begin{array}{l}42.93 \\
\pm 3.53\end{array}$ & 32.91 & 55.35 & 3.85 & 0.00 & 2.24 & 4.92 & 0.51 & 0.00 & 1.49 & 1.97 & 0.912 \\
\hline \multicolumn{3}{|c|}{ Wet gluten content $(\%)$} & WG & $\begin{array}{c}35.41 \\
\pm 10.06\end{array}$ & $\begin{array}{l}34.45 \\
\pm 3.33\end{array}$ & $\begin{array}{l}29.99 \\
\pm 9.46\end{array}$ & $\begin{array}{l}40.36 \\
\pm 9.65\end{array}$ & 10.85 & 61.60 & 52.03 & 0.94 & 9.53 & 12.27 & 2.45 & 0.04 & 4.79 & 3.78 & 0.928 \\
\hline \multicolumn{3}{|c|}{ Gluten index } & GI & $\begin{array}{c}79.11 \\
\pm 17.92\end{array}$ & $\begin{array}{c}81.30 \\
\pm 15.54\end{array}$ & $\begin{array}{c}83.76 \\
\pm 17.61\end{array}$ & $\begin{array}{c}74.39 \\
\pm 17.85\end{array}$ & 6.12 & 99.50 & 24.46 & 0.00 & 173.26 & 2.51 & 82.56 & 0.00 & 7.53 & 39.02 & 0.935 \\
\hline \multicolumn{3}{|c|}{$\begin{array}{l}\text { Thousand grain weight } \\
\text { (g) }\end{array}$} & TGW & $\begin{array}{l}46.46 \\
\pm 6.31\end{array}$ & $\begin{array}{l}45.00 \\
\pm 4.77\end{array}$ & $\begin{array}{l}45.11 \\
\pm 7.21\end{array}$ & $\begin{array}{l}48.11 \\
\pm 5.54\end{array}$ & 29.83 & 69.18 & 0.00 & 0.00 & 25.96 & $\underline{7.97}$ & 2.73 & 0.00 & 2.20 & 3.98 & 0.977 \\
\hline \multicolumn{3}{|c|}{ Grain diameter (mm) } & GD & $\begin{array}{c}3.15 \\
\pm 0.18\end{array}$ & $\begin{array}{c}3.11 \\
\pm 0.15\end{array}$ & $\begin{array}{c}3.12 \\
\pm 0.19\end{array}$ & $\begin{array}{c}3.18 \\
\pm 0.17\end{array}$ & 2.60 & 3.70 & 0.00 & 0.00 & 0.02 & 0.01 & 0.00 & 0.00 & 0.00 & 0.00 & 0.973 \\
\hline \multicolumn{3}{|c|}{ Grain length (mm) } & GL & $\begin{array}{c}7.22 \\
\pm 0.39\end{array}$ & $\begin{array}{c}7.10 \\
\pm 0.38\end{array}$ & $\begin{array}{c}7.19 \\
\pm 0.37\end{array}$ & $\begin{array}{c}7.29 \\
\pm 0.40\end{array}$ & 6.40 & 8.30 & 0.04 & 0.00 & 0.10 & 0.01 & 0.01 & 0.00 & $\underline{0.00}$ & 0.01 & 0.981 \\
\hline \multicolumn{3}{|c|}{ Yellow index } & YI & $\begin{array}{l}22.48 \\
\pm 2.34\end{array}$ & $\begin{array}{l}23.22 \\
\pm 2.17\end{array}$ & $\begin{array}{l}22.30 \\
\pm 2.47\end{array}$ & $\begin{array}{l}22.37 \\
\pm 2.26\end{array}$ & 16.55 & 27.68 & 0.78 & 0.21 & 2.69 & 0.50 & 1.04 & 0.00 & 0.07 & 0.78 & 0.945 \\
\hline \multirow[b]{2}{*}{ Trait } & \multicolumn{9}{|c|}{ Conventional conditions } & \multicolumn{9}{|c|}{ Organic conditions } \\
\hline & $\begin{array}{c}\text { Mean } \\
\pm \text { std }\end{array}$ & $\mathbf{A}$ & $\mathbf{F}$ & $\mathbf{H}$ & $\sigma_{E}^{2}$ & $\sigma_{G}^{2}$ & $\sigma_{G \times E}^{2}$ & $\sigma_{e}^{2}$ & $h^{2}$ & $\begin{array}{c}\text { Mean } \\
\pm \text { std }\end{array}$ & $\mathbf{A}$ & $\mathbf{F}$ & $\mathbf{H}$ & $\sigma_{E}^{2}$ & $\sigma_{G}^{2}$ & $\sigma_{G \times E}^{2}$ & $\sigma_{e}^{2}$ & $h^{2}$ \\
\hline GY & $\begin{array}{c}4.88 \\
\pm 2.38\end{array}$ & $\begin{array}{c}4.72 \\
\pm 1.57\end{array}$ & $\begin{array}{c}4.50 \\
\pm 0.89\end{array}$ & $\begin{array}{c}5.29 \\
\pm 3.43\end{array}$ & 5.4 & 0.07 & 0.4 & 0.4 & 0.510 & $\begin{array}{c}3.83 \\
\pm 1.51\end{array}$ & $\begin{array}{c}4.38 \\
\pm 0.80\end{array}$ & $\begin{array}{c}3.33 \\
\pm 0.87\end{array}$ & $\begin{array}{c}3.70 \\
\pm 2.07\end{array}$ & 1.26 & 0.15 & 0.75 & 0.24 & 0.583 \\
\hline HT & $\begin{array}{l}15.54 \\
\pm 7.75\end{array}$ & $\begin{array}{l}22.11 \\
\pm 2.20\end{array}$ & $\begin{array}{c}6.55 \\
\pm 3.22\end{array}$ & $\begin{array}{l}16.67 \\
\pm 5.04\end{array}$ & 51.41 & 2.57 & 1.95 & 1.5 & 0.887 & $\begin{array}{l}14.94 \\
\pm 8.30\end{array}$ & $\begin{array}{l}21.55 \\
\pm 2.78\end{array}$ & $\begin{array}{c}5.10 \\
\pm 3.83\end{array}$ & $\begin{array}{l}17.67 \\
\pm 4.57\end{array}$ & 58.15 & 4.70 & 1.47 & 0.82 & 0.953 \\
\hline $\mathrm{PH}$ & $\begin{array}{c}81.11 \\
\pm 15.68\end{array}$ & $\begin{array}{c}86.10 \\
\pm 12.67\end{array}$ & $\begin{array}{l}86.83 \\
\pm 6.80\end{array}$ & $\begin{array}{c}76.69 \\
\pm 17.79\end{array}$ & 235.6 & 16.42 & 14.36 & 14.1 & 0.851 & $\begin{array}{c}78.46 \\
\pm 14.92\end{array}$ & $\begin{array}{l}73.40 \\
\pm 6.36\end{array}$ & $\begin{array}{l}86.85 \\
\pm 6.31\end{array}$ & $\begin{array}{c}78.56 \\
\pm 18.73\end{array}$ & 209.41 & 12.69 & $\underline{8.53}$ & 19.05 & 0.837 \\
\hline GP & $\begin{array}{l}14.52 \\
\pm 2.96\end{array}$ & $\begin{array}{l}14.02 \\
\pm 1.94\end{array}$ & $\begin{array}{l}13.99 \\
\pm 2.67\end{array}$ & $\begin{array}{l}15.16 \\
\pm 3.38\end{array}$ & 5.79 & 0.72 & 0.76 & 0.29 & 0.864 & $\begin{array}{l}13.62 \\
\pm 3.41\end{array}$ & $\begin{array}{l}13.88 \\
\pm 1.85\end{array}$ & $\begin{array}{l}11.55 \\
\pm 2.45\end{array}$ & $\begin{array}{l}15.25 \\
\pm 3.60\end{array}$ & 8.28 & 0.91 & 0.67 & 0.45 & 0.890 \\
\hline SY & $\begin{array}{l}42.73 \\
\pm 4.05\end{array}$ & $\begin{array}{l}43.47 \\
\pm 2.81\end{array}$ & $\begin{array}{l}41.69 \\
\pm 4.33\end{array}$ & $\begin{array}{l}43.38 \\
\pm 4.02\end{array}$ & 11.22 & 2.79 & 2.44 & 1.84 & 0.869 & $\begin{array}{l}43.84 \\
\pm 3.16\end{array}$ & $\begin{array}{l}42.72 \\
\pm 3.13\end{array}$ & $\begin{array}{l}45.91 \\
\pm 2.20\end{array}$ & $\begin{array}{l}42.52 \\
\pm 2.97\end{array}$ & 6.76 & 1.59 & 1.59 & 2.12 & 0.828 \\
\hline WG & $\begin{array}{l}36.58 \\
\pm 8.40\end{array}$ & $\begin{array}{l}34.42 \\
\pm 3.62\end{array}$ & $\begin{array}{l}33.84 \\
\pm 8.50\end{array}$ & $\begin{array}{l}39.77 \\
\pm 8.51\end{array}$ & 38.8 & 9.79 & 6.42 & 3.39 & 0.906 & $\begin{array}{c}34.27 \\
\pm 11.35\end{array}$ & $\begin{array}{l}34.48 \\
\pm 3.06\end{array}$ & $\begin{array}{l}26.14 \\
\pm 8.83\end{array}$ & $\begin{array}{c}40.92 \\
\pm 10.63\end{array}$ & 89.63 & 9.75 & 8.44 & 4.03 & 0.882 \\
\hline GI & $\begin{array}{c}79.35 \\
\pm 17.59\end{array}$ & $\begin{array}{c}82.68 \\
\pm 14.24\end{array}$ & $\begin{array}{c}83.24 \\
\pm 15.97\end{array}$ & $\begin{array}{c}74.73 \\
\pm 19.03\end{array}$ & 26.91 & 166.74 & 92.95 & 33.8 & 0.924 & $\begin{array}{c}78.87 \\
\pm 18.27\end{array}$ & $\begin{array}{c}79.92 \\
\pm 16.84\end{array}$ & $\begin{array}{c}84.27 \\
\pm 19.19\end{array}$ & $\begin{array}{c}74.06 \\
\pm 16.76\end{array}$ & 27.15 & 172.65 & 95.50 & 44.02 & 0.922 \\
\hline TGW & $\begin{array}{l}46.09 \\
\pm 6.37\end{array}$ & $\begin{array}{l}43.67 \\
\pm 4.61\end{array}$ & $\begin{array}{l}44.75 \\
\pm 7.69\end{array}$ & $\begin{array}{l}48.14 \\
\pm 4.90\end{array}$ & 11.4 & 22.71 & 4.87 & 3.8 & 0.964 & $\begin{array}{l}46.81 \\
\pm 6.24\end{array}$ & $\begin{array}{l}46.32 \\
\pm 4.61\end{array}$ & $\begin{array}{l}45.47 \\
\pm 6.72\end{array}$ & $\begin{array}{l}48.08 \\
\pm 6.11\end{array}$ & 5.43 & 28.68 & 4.91 & 4.29 & 0.970 \\
\hline GD & $\begin{array}{c}3.14 \\
\pm 0.18\end{array}$ & $\begin{array}{c}3.07 \\
\pm 0.14\end{array}$ & $\begin{array}{c}3.11 \\
\pm 0.22\end{array}$ & $\begin{array}{c}3.18 \\
\pm 0.15\end{array}$ & 0.01 & 0.02 & $\mathbf{0}$ & 0 & 0.962 & $\begin{array}{c}3.16 \\
\pm 0.17\end{array}$ & $\begin{array}{c}3.15 \\
\pm 0.14\end{array}$ & $\begin{array}{c}3.12 \\
\pm 0.16\end{array}$ & $\begin{array}{c}3.18 \\
\pm 0.18\end{array}$ & 0.00 & 0.02 & 0.01 & 0.00 & 0.961 \\
\hline GL & $\begin{array}{c}7.24 \\
\pm 0.37\end{array}$ & $\begin{array}{c}7.09 \\
\pm 0.38\end{array}$ & $\begin{array}{c}7.28 \\
\pm 0.34\end{array}$ & $\begin{array}{c}7.26 \\
\pm 0.39\end{array}$ & 0.04 & 0.1 & 0.01 & 0.01 & 0.979 & $\begin{array}{c}7.20 \\
\pm 0.41\end{array}$ & $\begin{array}{c}7.12 \\
\pm 0.37\end{array}$ & $\begin{array}{c}7.11 \\
\pm 0.39\end{array}$ & $\begin{array}{c}7.31 \\
\pm 0.41\end{array}$ & 0.06 & 0.10 & 0.01 & 0.01 & 0.973 \\
\hline YI & $\begin{array}{l}22.81 \\
\pm 2.26\end{array}$ & $\begin{array}{l}23.54 \\
\pm 2.07\end{array}$ & $\begin{array}{l}22.99 \\
\pm 2.45\end{array}$ & $\begin{array}{l}22.38 \\
\pm 2.08\end{array}$ & 0.64 & 2.81 & 1.21 & 0.63 & 0.936 & $\begin{array}{l}22.16 \\
\pm 2.38\end{array}$ & $\begin{array}{l}22.89 \\
\pm 2.25\end{array}$ & $\begin{array}{l}21.62 \\
\pm 2.30\end{array}$ & $\begin{array}{l}22.37 \\
\pm 2.42\end{array}$ & 1.92 & 2.57 & 0.79 & 1.03 & 0.941 \\
\hline
\end{tabular}

Note: $\sigma^{2}=$ variance component for $E$ : environment (year $\times$ country combination), $M$ : management system, $G$ : genotype and their interactions; $\sigma_{e}^{2}=$ variance of the residual error. Variance components in bold, underlined and in italics are significant at $\mathrm{P} \leq 0.001, \mathrm{P} \leq 0.01$ and $\mathrm{P} \leq 0.05$, respectively. $h^{2}$ refers to the repeatability (broad-sense heritability) of the traits tested. 
Online Resource 4 Phenotypic correlation coefficients $\left(r_{p}\right)$ between the best linear unbiased estimators (BLUEs) among the data of 14 winter durum wheat genotypes grown under organic (below diagonal) and conventional (above diagonal) field conditions, evaluated for 11 agronomic, phenotypic and technological quality traits assessed in Austria, France and Hungary in the period 20112013

\begin{tabular}{|c|c|c|c|c|c|c|c|c|c|c|c|}
\hline $\begin{array}{c}\text { Trait } \\
\text { (abbre } \\
\text { via } \\
\text { tion) }\end{array}$ & $\begin{array}{l}\text { Grain } \\
\text { yield } \\
(G Y)\end{array}$ & $\begin{array}{c}\text { Heading } \\
\text { time } \\
(\text { HT) }\end{array}$ & $\begin{array}{c}\text { Plant } \\
\text { height } \\
\text { (PH) }\end{array}$ & $\begin{array}{c}\text { Grain } \\
\text { protein } \\
\text { content } \\
(\text { GP) }\end{array}$ & $\begin{array}{c}\text { Semolina } \\
\text { yield } \\
\text { (SY) }\end{array}$ & $\begin{array}{c}\text { Wet } \\
\text { gluten } \\
\text { content } \\
\text { (WG) }\end{array}$ & $\begin{array}{c}\text { Gluten } \\
\text { index } \\
\text { (GI) }\end{array}$ & $\begin{array}{c}\text { Thousand } \\
\text { grain } \\
\text { weight } \\
\text { (TGW) }\end{array}$ & $\begin{array}{c}\text { Grain } \\
\text { diameter } \\
\text { (GD) }\end{array}$ & $\begin{array}{c}\text { Grain } \\
\text { length } \\
\text { (GL) }\end{array}$ & $\begin{array}{c}\text { Yellow } \\
\text { index } \\
\text { (YI) }\end{array}$ \\
\hline GY & $0.65 * * *$ & $0.34 * * *$ & $0.54 * * *$ & $-0.69^{* * *}$ & $\underline{0.61}^{* * *}$ & $-0.58 * * *$ & $0.29 * * *$ & 0.08 & -0.01 & $-0.32 * * *$ & -0.05 \\
\hline HT & $0.41 * * *$ & $0.95 * * *$ & $0.34 * * *$ & $-0.32 * * *$ & $0.39 * * *$ & $-0.17 * *$ & -0.04 & -0.01 & -0.06 & $-0.33 * * *$ & 0.09 \\
\hline PH & $0.59 * * *$ & -0.07 & $0.69 * * *$ & $-0.53 * * *$ & $0.25 * * *$ & $-0.57 * * *$ & $0.22 * * *$ & $-0.11^{*}$ & -0.06 & $-0.33 * * *$ & 0.04 \\
\hline GP & $-0.48 * * *$ & $0.16^{* *}$ & $-0.62 * * *$ & $0.86 * * *$ & $-0.48 * * *$ & $0.82 * * *$ & $-0.26^{* * * *}$ & 0.04 & 0.09 & $0.57 * * *$ & -0.02 \\
\hline SY & 0.09 & $-0.38 * * *$ & $0.28 * * *$ & $-0.44 * * *$ & $0.45 * * *$ & $-0.41 * * *$ & 0.01 & $0.41 * * *$ & $0.42 * * *$ & $-0.16^{* *}$ & $-0.32 * * *$ \\
\hline WG & $-0.40 * * *$ & $0.32 * * *$ & $-0.57 * * *$ & $0.89 * * *$ & $-0.34 * * *$ & $0.85 * * *$ & $-0.53 * * *$ & 0.02 & 0.03 & $0.43 * * *$ & -0.03 \\
\hline GI & $0.29 * * *$ & $-0.17 * *$ & $0.23 * * *$ & $-0.32 * * *$ & 0.07 & $-0.46 * * *$ & $0.96 * * *$ & -0.07 & $-0.15^{* *}$ & $-0.30 * * *$ & $0.23 * * *$ \\
\hline TGW & $0.15^{* *}$ & 0.01 & 0.07 & $0.35 * * *$ & $0.15 * *$ & $0.31 * * *$ & -0.09 & $0.71 * * *$ & $0.93 * * *$ & $0.57 * * *$ & $-0.43 * * *$ \\
\hline GD & $0.12^{*}$ & -0.01 & 0.11 & $0.28 * * *$ & $0.18^{* *}$ & $0.19 * * *$ & $-0.15^{* *}$ & $0.91 * * *$ & $0.77 * * *$ & $0.47 * * *$ & $-0.53 * * *$ \\
\hline GL & $-0.24 * * *$ & -0.06 & $-0.23 * * *$ & $0.59 * * *$ & $-0.14 *$ & $0.48 * * *$ & $-0.34 * * *$ & $\underline{0.71} * * *$ & $0.56^{* * * *}$ & $0.94 * * *$ & $-0.15^{* *}$ \\
\hline YI & 0.03 & $0.24 * * *$ & -0.09 & $0.23 * * *$ & $-0.35 * * *$ & $0.30 * * *$ & $0.12 *$ & $-0.21 * * *$ & $-0.41 * * *$ & 0.01 & $0.91 * * *$ \\
\hline
\end{tabular}

Note: very strong $\left(r_{P} \geq 0.8\right)$, strong $\left(0.6 \leq r_{P}<0.8\right)$ and moderate $\left(0.4 \leq r_{P}<0.6\right)$ correlations are marked by bold, underlined and italics, respectively; $*$,**,*** significant at the $0.05,0.01,0.001$ probability level, respectively;

Diagonal represents the correlation between the management systems based on three countries (grey cells: not significant in Austria). 